\title{
Usage and Impact Factor Correlations in Electronic Journals
}

\author{
by \\ Emma Jane Shepheard-Walwyn
}
Submitted to the School of Information Management,
Victoria University of Wellington in partial fulfilment of the requirements for the degree of Master of Library and Information Studies

June 2009 


\section{ACKNOWLEDGEMENTS}

I would like to thank my family, friends and colleagues, without whose support and encouragement this project could not have been completed. I also thank my supervisor Alastair Smith, whose support, insight and patience have been invaluable. 


\section{CONTENTS}

1 THE PROBLEM 1

1.1 Introduction 1

1.2 Problem Statement 1

1.3 Research Questions 2

1.4 Limitations of this Study 3

2 LITERATURE REVIEW 5

3 RESEARCH METHODOLOGY AND DATA ANALYSIS 18

4 RESULTS 22

4.1 Faculty of Humanities \& Social Science 26

$\begin{array}{lll}4.2 & \text { Faculty of Science } & 30\end{array}$

4.3 Faculty of Commerce \& Administration 34

$\begin{array}{lll}4.4 & \text { Faculty of Law } & 38\end{array}$

5 CONCLUSION 40

6 APPENDIXES 45

6.1 Table: History Discipline - VUW Usage Statistics and ISI Impact 45

Factors

6.2 Table: Linguistics Discipline - VUW Usage Statistics and ISI 46 Impact Factors

6.3 Table: Political Science Discipline - VUW Usage Statistics and ISI 48 Impact Factors

6.4 Table: Environmental Science Discipline - VUW Usage Statistics 50 and ISI Impact Factors

6.5 Table: Mathematics Discipline - VUW Usage Statistics and ISI 52 Impact Factors

6.6 Table: Physics (Applied) Discipline - VUW Usage Statistics and ISI 54 Impact Factors

6.7 Table: Economics Discipline - VUW Usage Statistics and ISI Impact 56 Factors

6.8 Table: Library Science \& Information Science Discipline - VUW 59 Usage Statistics and ISI Impact Factors

6.9 Table: Management Discipline - VUW Usage Statistics and ISI 61 Impact Factors

6.10 Table: Law Discipline - VUW Usage Statistics and ISI Impact 63 Factors

$\begin{array}{lll}7 & \text { BIBLIOGRAPHY } & 65\end{array}$ 


\section{LIST OF TABLES AND FIGURES}

Figure 1: Summary of Key Benefits and Criticisms Associated with ISI Impact Factor Use

$\begin{array}{lr}\text { Figure 2: Disciplines Selected for Study } & 18\end{array}$

Figure 3: VUW Usage Statistics by Information Provider for Applied Linguistics

Figure 4: Information Providers Included in ISI's Journal Use Report

Figure 5: Titles Appearing on Multiple Discipline Lists

Figure 6: History Discipline - VUW Usage Statistics and ISI Impact Factors

Figure 7: Linguistics Discipline - VUW Usage Statistics and ISI Impact Factors

Figure 8: Political Science Discipline - VUW Usage Statistics and ISI Impact Factors

Figure 9a: Environmental Science Discipline - VUW Usage Statistics and ISI Impact Factors

Figure 9b: Environmental Science Discipline - VUW Usage Statistics and ISI Impact Factors - Adjusted

Figure 10: Mathematics Discipline - VUW Usage Statistics and ISI Impact Factors

Figure 11: Physics (Applied) Discipline - VUW Usage Statistics and ISI Impact Factors

Figure 12: Economics Discipline - VUW Usage Statistics and ISI Impact Factors

Figure 13: Library Science \& Information Science Discipline - VUW Usage 36 Statistics and ISI Impact Factors

Figure 14: Management Discipline - VUW Usage Statistics and ISI Impact Factors

Figure 15: Law Discipline - VUW Usage Statistics and ISI Impact Factors 38

Figure 16: Summary of Correlation Levels by Faculty and Discipline $\quad 40$

Figure 17: All Disciplines - VUW Usage Statistics and ISI Impact Factors 


\section{ABSTRACT}

This research explores the level of correlation between electronic journal usage and ISI Impact Factors that may justify Impact Factors to be used as a collection management tool. The study utilised ISI's Journal Use Report and Journal Citation Reports to gather data in the areas of History, Linguistics, Political Science, Environmental Science, Mathematics, Physics (Applied), Economics, Information Science \& Library Science, Management and Law.

A slight positive correlation was found for several disciplines with two disciplines displaying a small negative correlation. The study concluded that the levels of correlation were not significant enough to enable ISI Impact Factors to be used in isolation as an effective collection management decision-making tool.

Several issues were identified as possible factors in the level of correlation found: articles downloaded and not used, the limited number of titles subscribed to by VUW, the lack of New Zealand and Australasian titles, the interdisciplinary nature or limited focus of some titles and the research and teaching focus of VUW.

The study concludes that Impact Factors may be of use as an evaluation tool for academic libraries, but that they should be used in combination with a number of other factors discussed. A number of areas for further research are also identified.

\section{Keywords:}

Collection Management; Electronic Journals; Usage Statistics; Impact Factors; Academic Libraries; New Zealand. 


\section{THE PROBLEM}

\subsection{Introduction}

The problem of effectively evaluating electronic journals is something that has faced academic libraries since electronic journals have reached the academic market. As each new print or electronic journal evaluation tool has been developed, academic researchers have investigated their merits and disadvantages. Citation-based evaluation tools have been developed not only as a measure of journal merit for researchers, but also as a tool for librarians in ascertaining the value of title acquisition. While a variety of citation-based evaluation tools have been used in an attempt to meet collection management decision-making needs, few studies have used metrics to analyse the level of correlation these evaluation tools have with electronic journal usage statistics in a New Zealand environment.

\subsection{Problem Statement}

As the popularity of and demand for electronic journals rise, academic librarians may find it helpful to discover an effective evaluation tool for collection management decision-making. Local usage studies can be time consuming and labour intensive, unsuitable as a regular evaluation tool. Although there are a number of evaluation tools employed by libraries, citation-based journal-ranking tools offer an additional element to the academic librarian's arsenal. A variety of journal-ranking systems have been developed and are now readily available for use as journal evaluation tools. These include, ISI Impact Factors (Web of Knowledge, 2008), Eigenfactor (Bergstrom, 2007), SCImago Journal and Country Rank (SCImago, 2007) and Red Jasper's Centre for Journal Ranking (Red Jasper's Centre for Journal Ranking, 2006). 
Librarians are now faced with a variety of journal ranking systems that because of their range are of varying degrees of usefulness in collection management decisionmaking. What is needed is further research into the correlation between current subscription usage and journal ranking systems to discover to what extent journal ranking systems are viable collection management decision-making tools.

This project aims to discover the level of correlation between electronic journal usage statistics at Victoria University of Wellington (VUW) and one evaluation tool widely available to academic libraries - ISI Impact Factors. If a significant positive relationship is found, then ISI Impact Factors may be able to be used as a collection management decision-making tool. If a strong relationship is not found, the extent to which ISI Impact Factors may be used in tandem with other evaluation tools will be discussed.

\subsection{Research Question}

This research seeks to answer the following question:

"What level of correlation is there between usage statistics for electronic journals at Victoria University of Wellington Library (VUW) and the journal rankings produced by ISI that may enable ISI Impact Factors to be used as an effective collection management decision-making tool?”

The sub questions are as follows:

1. Is there a statistically significant relationship between the VUW usage statistics and the ISI Impact Factor of a journal title?

2. Is there a statistically more significant correlation in a particular discipline than in another? 


\subsection{Limitations of this Study}

The following limitations have been identified:

1. In terms of electronic journal articles, 'use' is defined as 'download'.

As discussed in the literature review, this definition of calculating electronic journal use compares favourably with the 'sweep' survey method commonly used in localised print journal frequency of use studies (Tsay, 1998, 32-33). The 'sweep' survey method counts print journals, as they are re-shelved after being picked up from tables and carts where they were left by users. This method is an effective measure of use in academic libraries where print journals are not available to be withdrawn.

The 'sweep' method of calculating print journal use compares favourably with electronic journal article downloads or 'use.' One limitation of the 'sweep' survey method is that it does not count volumes that are immediately re-shelved by patrons, as the use is negligible. The immediate re-shelving of a journal indicates that the patron made little if any use of the item. Similarly, this study will only count full article downloads as a 'use.' Like the immediate re-shelving of a print journal, the viewing of electronic abstract or other bibliographical information without downloading the full electronic article indicates that the patron made little if any use of the item. The extent to which this assumption holds true in practice is outside the scope of this project, but would make an interesting topic of research. 
2. Actual use of an article once it has been successfully downloaded cannot be ascertained.

Once an article has been successfully downloaded it may be cited in research, read to increase knowledge, or not used at all. Due to the ease with which journal articles can be downloaded, it is possible that users may download articles for a cursory glance, much as one would browse a journal abstract. As discussed further in the methodology, this project will utilise ISI's Journal Use Report as a means of gathering usage statistics for the electronic journals VUW subscribes to. In spite of the limitation mentioned above, the Journal Use Report remains the timeliest and most cost effective method of gathering usage statistics within the scope of this project.

3. Victoria University of Wellington Library does not subscribe to all journals included in the Journal Citation Report.

As this study is based on electronic journal usage at Victoria University of Wellington, any titles not subscribed to by VUW Library will be excluded from this study.

4. Not all journals subscribed to by Victoria University of Wellington are included in the Journal Citation Report.

Impact Factors cannot be gathered for journals not included in the Journal Citation Report, so these titles will be excluded from this study. This limitation is apparent with the other citation-based evaluation tools mentioned above. The 
Journal Citation Report contains the largest, most current list of journal titles available to the author. However, the fact that many New Zealand journal titles are not included in this study may affect the validity of the results. The implications of this will be discussed further in the results.

\section{LITERATURE REVIEW AND THEORETICAL FRAMEWORK}

The use of journal citation and impact as evaluation tools has been continually addressed by scholars since the annual publication of ISI Journal Citation Reports commenced in 1976. The proposed research study aims to address a previously neglected area of investigation from a New Zealand perspective - the level of correlation found between electronic journal usage statistics and ISI Impact Factors. The intention of this study is to establish the validity of impact factors as a collection management tool in academic libraries. The parameters of the literature review were established from initial working hypotheses that there was little scholarship on the validity of impact factors as a collection management tool in academic libraries for electronic journals from a New Zealand or Australasian perspective, and that there were very few recent studies in this area. Both of these working hypotheses appeared to be supported by an initial review of the literature.

\section{ISI Impact Factor}

The earliest use of citation data in collection management decisions was in 1927, where faculty members at Pamona College ranked chemistry journals according to the number of times they were cited in the 1926 volume of Journal of the American

Chemical Society (Nisonger, 2004, 59). As Nisonger $(2004,59)$ notes, early attempts 
at citation based journal ranking were labour intensive and methodically flawed due to varying back runs.

The Institute for Scientific Information (ISI) attempted to solve this problem through the development of Impact Factors - a measurement of a journal's impact on a field of study - in the early 1960s. The Impact Factor of a journal title represents the number of cites to recent articles divided by the number of recent articles from the same journal title contained in the ISI database:

Impact Factor $($ year 3) $=\underline{\text { Number of citations received }(\text { year } 3) \text { to citable items published }(\text { year } 1+2)}$ Number of citable items published (year $1+2$ )

For example, from the ISI Science Citation Index Journal Citation Reports, the Impact Factor for Harvard Law Review in 2006 is 7.863:

Impact factor $2006=\frac{(432+315)}{(50+45)}=\frac{747}{95}=7.863$

Where journal articles published in 2006 cited articles published by Harvard Law Review in 2004 and 2005, 747 times. Of this, 432 citations were made to 50 articles published by Harvard Law Review in 2004, and 315 citations were made to 45 articles published in 2005.

Although the two-year Impact Factor is the most commonly used tool from the Journal Citation Reports, it is only one of several quantitative and qualitative measures available (Garfield, 1990). Another measure relevant to this project is the Five-Year Impact Factor. This journal-ranking tool is available as part of the Journal Citation Reports. It measures citations over five years, instead of the traditional two years. This formula gives a better indication of the long-term value of a journal 
(Rousseau, 2002). This is also the citation period utilised by Red Jasper's Centre for Journal Ranking (2006).

In the 2007 edition of the ISI Journal Citation Reports, the Science Citation Index indexed 6,426 journal titles (ISI Web of Knowledge, 2008). The Social Science Citation Index consisted of 1,800 journal titles. ISI follows a selective procedure for evaluating journal titles for the inclusion in the Journal Citation Reports, and as Rousseau (2002) notes, citations, and hence Impact Factor, will always be calculated from a limited pool of journal titles. The implications for this project are that New Zealand, and to a lesser extent Australasian, titles are not well represented.

The characteristics of a quality journal were illustrated by Zwemer (1970). The key elements include:

- High standards of acceptance for manuscripts - specifically articles based on new scientific information, reliable methods, adequate controls and treatment of statistical data;

- A broad editorial board with appropriate representation of all disciplines and sub-disciplines covered by the journal;

- A critical refereeing system is used;

- Ability to meet the declared publishing schedule and frequency;

- Inclusion of journal title in key abstract and indexing services;

- Confidence in the contents is high among the scientific community; and

- Achieves a high citation rate in other journals. 
The elements of citation data, journal standards and expert judgement were also used by Garfield (1990) to illustrate the selection process of journals for the inclusion in the products offered by ISI. Garfield also notes that fully descriptive article titles and abstracts, complete bibliographic information, the reputation of a publisher, and English language abstracts are also key factors (1990, 192).

\section{Research Focused Studies of Citation-based Journal Ranking Tools}

Nisonger (2004) provided an overview of the studies that have been carried out in relation to the Journal Citation Report Impact Factor. In discussing the benefits and criticisms of using Impact Factors as a collection management tool, Nisonger concludes that Impact Factor should be viewed as a valid and reliable collection management tool, as long as it is used with the following guidelines (2004, 71-72):

- The Impact factor should be considered in combination with other journal evaluation criteria (library collection priorities, subjective judgement of the journal's quality, cost, indexing, use and alternative forms of availability);

- Journals from different disciplines should not be compared;

- More than one years data should be used;

- Impact Factors from adjacent years should not be averaged (it would be more correct to adjust the formula for the number of years you wish to analyse);

- Title changes can alter a journal's Impact Factor (citations to the old title are not transferred to the new title);

- A low Impact Factor does not necessarily indicate a 'bad' journal title;

Nisonger $(2004,72)$ also notes that correction for journal self-citation and other statistical manipulations discussed in the literature would not merit the effort required. 
Nisonger's guidelines raise several implications for the proposed study. The correlation between use and Impact Factor may differ between disciplines. This study proposes to look at the level of correlation between Impact Factor and VUW usage statistics within disciplines, not compare individual journal rankings between journals of different disciplines. This study also proposes to not include data from any journal that has changed its title within the last two years. As citations from the old title do not relate to the new title, this would result in incomplete data if used. Another point to note in the discussion of results is that a low Impact Factor may not indicate a 'bad' journal. It should be noted that a title may be valuable for other purposes than contributing to research, such as a teaching tool in academic libraries, or of use to practitioners in private practices.

In assessing the reliability of ISI Impact Factors being used to evaluate research, Seglen $(1997,499)$ notes that the use of journal impact factors conceals differences in article citation rates. In a study of nine biochemical journals, Seglen shows that $50 \%$ of citations come from $15 \%$ of a journal's articles and that $90 \%$ of citations come from $50 \%$ of a journal's articles. By assigning a journal Impact Factor to a journal title rather than an article, Seglen argues that uncited articles (roughly $50 \%$ of a journal's articles) are sharing the glory of a few cited articles, making the Impact Factor non-representative of the whole. This problem does not negate the use of Impact Factors as a collection management tool. It is inevitable that part of a resource many be more heavily used than another part. This holds true for any resource, regardless of format.

Seglen also discusses the 'shortcomings of a technical and more fundamental nature' that the Impact Factors are encumbered with $(1997,500)$. Many of Seglen's 
perceived problems associated with Impact Factors are shared with a number of other authors (Altmann and Gorman, 1999; Duy and Vaughan, 2006). The main points are that Impact Factors may be determined by a formula that does not signify the scientific quality of articles, and that Impact Factors may vary according to research field - journals covering large areas of research with rapidly expanding but shortlived literature will result in a higher impact factor than an area of research with a longer literature life (Seglen, 1997, 499).

Garfield (1990) also notes that the number of citations an article received may vary between disciplines. He goes on to mention that smaller fields may not generate as many articles or citations as larger disciplines, and that while it may take 10 or more years for an article to attract a meaningful number of citations in one field, in another field the number of citations could peak within a few years. This issue only becomes pertinent when one compares the rankings of individual journal titles in separate disciplines. This research study will be looking at the level of correlation within each discipline, rendering this point moot.

Levitt and Thelwall (2008) used citation analysis to determine whether research published in interdisciplinary journals were more highly cited than articles in specific fields of study. Their finding was that the citation rates of articles published in journals in specific fields of study were significantly higher than articles published in interdisciplinary journals. While this study will not be looking at the interdisciplinary nature of titles, this may be a discussion point when looking at the levels of correlation between subject areas. For example, Environmental Science may be of a more interdisciplinary nature than Applied Physics. 
Rather than following Seglen's citation approach (1997), Saha (2003) tests the validity of impact factor as a measure of quality by testing its correlation with the quality ranking given by clinical practitioners and researchers. The study found strong correlations between Impact Factor and both clinical practitioners and researchers rankings. Saha concludes that Impact Factor may be a reasonable indicator of quality for general medical journals, despite its limitations $(2003,46)$.

\section{Collection Management Focused Studies of Citation-based Journal Ranking Tools}

Tsay (1998) explored the use, citation and Impact Factor data for highly used, highly cited or high Impact Factor journals through the Spearman rank correlation coefficient and Pearson product-moment correlation coefficient tests. Tsay's results indicated that the more frequently a journal is published, the more citations it is likely to receive $(1998,35)$. These results support Seglen's suggestion that journals, including rapidly increasing but short-lived literature, will result in a higher Impact Factor (1997, 499). Nisonger's guidelines $(2004,71-71)$ are also relevant here - that a low Impact Factor does not necessarily indicate a 'bad' journal, particularly in a slowly evolving field, and that Impact Factors from different disciplines should not be compared.

The 'sweep' survey method was utilised by Tsay to evaluate print journal use. Print journals are counted as they are re-shelved after being picked up from tables and carts where they were left by users. Although there are limitations associated with this method, it remains one of the most useful tools for estimating print journal usage. One of the limitations of this method is that it does not count volumes that are immediately re-shelved by patrons. However, if an item is immediately re-shelved, its use by patrons would be negligible (Tsay, 1998, 32-33). With the increase of 
electronic journals in academic libraries, print journal subscriptions should be reevaluated. While for some disciplines, such as Library Science \& Information Science, electronic access is preferred, for others the preference is for print. Disciplines such as Art History, Classics and Mathematics often prefer print due to the lack of clarity in images and formulae in electronic journals.

Tsay discusses further limitations of the study resulting from the selection of data. Library use data was collected for 1995, and Journal Citation Report data was collected for 1993. While Tsay notes that new titles would be disadvantaged by this limitation, he also noted that ranking based on citations would change little in two years for established titles: 'impact factors no doubt shift from year to year, but the relative rankings are probably more stable' (Tsay, 1998, 33). While this may be accurate for the disciplines analysed in this study, another study by Altmann and Gorman $(1998,151)$ noted that the median year-to-year variation in impact factors was $21.97 \%$ in ecology journals.

Tsay's study confirmed a statistically significant relationship existed between the frequency of use and the frequency of citations, and between the frequency of use and the Impact Factor for journals in the medical sciences. Although further research is needed to confirm these results across other disciplines, Tsay indicates that Impact Factor is 'a significant measure of importance that could be used for journal selection' $(1998,39)$.

Nixon and Wulff (2004) looked at the patterns of use of print and electronic journals and correlations with ISI Impact Factors in the biomedical field. The relationship between print and electronic journal usage is something not covered by earlier 
literature. Nixon and Wulff found that while people preferred to use the electronic version of a journal title over the print, journals that were highly used in print format were also highly used in electronic format $(2004,321)$. The study also found that that the level of correlation between Impact Factor and the electronic usage data produced by information providers differed considerably between providers $(2004,319)$. An analysis of the variances in Impact Factor and usage correlations by information provider is outside the scope of this project; however it would make an interesting topic for further research.

Duy and Vaughan $(2006,512)$ also examined the relationship between print and electronic measures of journal usage and citation data. With print usage studies being expensive and time-consuming (like the 'sweep' method employed by Tsay), the ability to track electronic journal usage through Journal Use Reports is a useful tool for librarians. COUNTER compliant electronic journal usage (qualified as the total number of HTML and PDF full-text articles requested) was gathered online directly from the publisher (Duy and Vaughan, 2006, 514). COUNTER (Counting Online Usage of NeTworked Electronic Resources) was established in March 2002 as an international initiative to provide librarians and other information specialists by 'setting standards and facilitate the recording and reporting of online usage statistics in a consistent, credible and compatible way' (COUNTER, 2006).

Using the Spearman's rank correlation coefficient and the Pearson product-moment correlation coefficient, the results of the Duy and Vaughan's study indicate that electronic usage data correlates significantly with print usage data in the areas of chemistry and biochemistry $(2006,516)$. The results also indicate that though is no relationship between electronic usage data and Impact Factor, there was a correlation 
with local citation data $(2006,515)$. Although no correlation was found, this study was confined to a limited number of journal titles. Further research is required to see whether similar results may occur across other disciplines.

A recent study by Chung $(2007,395)$ compared international citation data (Impact Factor) with local citation data. Local citation data was gathered from within the institution by counting the number of citations a journal received from the researchers within the institution. Using the Pearson product-moment correlation coefficient test, it was found that there was no significant relationship between the impact Factor and local citation score. Accordingly, Chung notes that the Impact Factor could not be substituted for a local use study $(2007,401)$.

The key benefits and criticisms associated with the use of ISI Impact Factors discussed above are summarised in Figure 1 below:

Figure 1: Summary of Key Benefits and Criticisms Associated with ISI Journal Impact Factor Use

Benefits:

- ISI Impact Factor is a well-known evaluation tool

- The formula is straightforward and easily comprehended

- Data is easily obtained from Journal Citation Reports

- It allows for comparison between different journals by normalising for their age and size

- Additional citation information is available from the Journal Citation Reports - including a journal's total citations received, immediacy index and cited half life

- Journals within an ISI subject category can be compared

Criticisms:

- The size and dynamic of a research field can influence the Impact Factor

- Research fields with rapidly increasing but short-lived literature are favoured

- The normalised variables (i.e. age and size of a journal) may be legitimate evaluation criteria

- Impact Factor may not correspond to journal use at an individual library

- Self citations are not corrected for

- Coverage of the Journal Citation Reports is not complete

- Database has an English language bias

- Database has an American publisher bias 


\section{Alternative Citation-based Journal Ranking Systems}

The use of ISI journal performance metrics as a systematic and objective evaluation tool has been the subject of wide debate (Seglen, 1997; Chung, 2007). In the view of the debate surrounding the validity of ISI's Impact Factor, other journal ranking options such as Eigenfactor, SCImago Journal and Country Rank and Red Jasper's Centre for Journal Ranking are providing alternative formulae for measuring a journal's impact.

Eigenfactor was designed to complement, rather than replace, traditional evaluation tools. A discussion of the advanced statistical formula used on the website is beyond the scope of this study. However, it does aim to solve many of the perceived deficiencies associated with the ISI Impact Factor for which the designers; Ted and Carl Bergstrom; were named SPARC Innovators by the Scholarly Publishing and Academic Resources Coalition (SPARC, 2007).

With data provided by Thomson Reuters (Scientific) Inc., the Eigenfactor algorithm works in a similar way to the Google pagerank algorithm by using the entire network of citations to evaluate the importance of each journal. It also uses five-year citation data and adjusts scores for citation differences across disciplines. The 115,000 items used in the database include scholarly journals, newsprint, $\mathrm{PhD}$ theses and popular magazines (Bergstrom, 2009).

The SCImago Journal and Country Rank (SJR) was developed by the SCImago Research Group, utilising information contained within the Elsevier database, Scopus. Scopus is one of the largest abstract and citation databases on the market; with over 16,000 peer-reviewed journals, including open-access journals, conference 
proceedings, trade publications, book series, and over 431 million web sources; covering such disciplines as Life Sciences, Health Sciences, Physical Sciences, and Social Sciences (Scopus, 2008).

Based on the Google PageRank algorithm, the SJR is based on the 'transfer of prestige', through the use of citations, from one journal to another (SCImago, 2007). Although a discussion of the formula used to calculate the SJR is beyond the scope of this study, the calculation involves three stages:

1. Initial assignation of the SJR, where a default prestige is assigned to a journal;

2. Interation process, where the computation from step 1 is interated to calculate the prestige of the journal;

3. Calculation of the prestige per article.

The Centre for Journal Ranking by Red Jasper Limited (CJR) is an interactive journal ranking service that allows users to configure their ranking interests (Red Jasper's Centre for Journal Ranking, 2006). Although CJR covers all disciplines, the database currently holds approximately 7,000 journals, making CJR the smallest ranking service discussed in this literature review. The CJR aims to provide an alternative journal ranking formula that resolves two commonly held problems with ranking systems using the Science Citation Index (SCI) as a base (Red Jasper's Centre for Journal Ranking, 2006):

- SCI assigns all citations with the same weighting. The CJR maintains that indirect contributions must be taken into account when evaluating a journal; 
- The discipline experts used by SCI may have preconceived biases in ranking journals due to their own experiences with a journal, or lack of them.

Like the SCImago Journal and Country Rank, the CJR uses Google's PageRank algorithm as a basis for their formula. Although further discussion of the CJR formula is outside the scope of this study, the formula proposes two new indicators by considering both journal influence index and the paper influence index. The formula allows users to validate various scenarios and parameters to rank journals.

Despite the merits of some of the alternative methods of calculating Impact Factor above, the decision was made to utilise the ISI Journal Citation Reports for this study for a number of reasons. Victoria University of Wellington Library has a current subscription to the ISI Web of Knowledge Journal Citation Reports package. Additionally, the Journal Citation Reports contained the most comprehensive and current data available to the author.

Due to the short history of the Eigenfactor, SCImago Journal and Country Rank and the Centre for Journal Ranking, there have been few studies on the merits of these tools to date. However, several of the limitations of ISI Impact Factors indicated in Figure 1 could be applied to these alternative systems. For example, each of these tools has an English language bias and an American publisher bias. Further investigation on the benefits and criticisms of these journal-ranking tools in comparison with ISI's Journal Citation Reports may be appropriate area for future scholarly study. It is noted that Eigenfactor will become part of the ISI Web of Knowledge Journal Citation Report package from 2009 (ISI Web of Knowledge, 2009). 


\section{RESEARCH METHODOLOGY AND DATA ANALYSIS}

The usage statistics for VUW were calculated using the ISI Journal Use Report for 2007. This report is COUNTER compliant and calculates the number of successful downloads of articles from a journal title for a specific time period. This method of calculation was chosen as the software is freely available to the author and involves limited resources.

The discipline categories used were those listed in the Journal Citation Reports. VUW discipline categories were unable to be used as the Journal Use Report; the medium through which the VUW usage statistics were supplied; had no facility to sort the results by discipline. A Journal Citation Report was run for each discipline listed in Figure 2. The titles in each discipline's Journal Citation Report were then matched up with the appropriate titles in the Journal Use Report.

Figure 2: Disciplines Selected for Study

\begin{tabular}{|l|l|}
\hline Faculty & Discipline \\
\hline Faculty of Humanities \& Social Science & History \\
& Linguistics \\
& Political Science \\
\hline Faculty of Science & Environmental Science \\
& Mathematics \\
& Physics (Applied) \\
\hline Faculty of Commerce \& Administration & Economics \\
& Information Science \& Library Science \\
& Management \\
\hline Faculty of Law & Law \\
\hline
\end{tabular}

These disciplines were chosen for two reasons:

a. to give a diverse range of subject matter to better allow trends in disciplines to emerge, and

b. these are disciplines that are either studied by students or researched by staff at VUW. 
Out of the seven faculties at Victoria University of Wellington, only four were selected for inclusion in this research study:

- The Faculty of Architecture and Design was excluded as no disciplines relating to this faculty were listed in the Journal Citation Reports.

- The Faculty of Engineering and Computer Science was excluded as the disciplines available in the Journal Citation Reports did not fit well within this faculty.

- The Faculty of Education is a recent addition to Victoria University of Wellington and has undergone several structural and programme changes. Although results were available for disciplines within this faculty, the decision was made not to include these as they would not reflect the new strategic directions of the faculty. This faculty could be an area for future study once the environment has stabilised.

Data for electronic journal use Usage statistics was gathered for up to 100 titles on each discipline's Journal Citation Report. As the Journal Citation Reports were not yet available with 2008 figures, the decision was made to use the Journal Usage Report for 2007. This ensured that both analysis tools are compared on an equal footing with data collected from the same time period.

The Journal Citation Reports for each discipline were be sorted by Impact Factor. Of the 10 disciplines selected, only three disciplines had Journal Citation Reports consisting of more than 100 titles. The limit of 100 titles was chosen due to the time restraints of this project. As the Impact Factor ratings were minimal after the first 100 titles of a Journal Citation Report and the number of subscriptions VUW had to journal titles with lower ratings decreased significantly, it was thought that this limit 
would still allow a range of high, medium and low Impact Factor titles to be analysed within the parameters of this study.

The titles in each discipline must be journal titles that Victoria University of Wellington Library subscribes to, and appear in the Journal Use Report. Those titles that were not subscribed to and did not appear in the Journal Use Report were excluded from the study. Data from any title that had had a name change within the last two years were also excluded from this study. As citation data from an old title does not relate to the new one, data for the new title name would be incomplete. If a title was excluded from the study by the above criteria and additional titles are available (i.e. the Journal Citation Report contained more than 100 titles), replacement titles were not selected.

The results for each discipline were placed in a table noting the Journal Title, ISSN, VUW Usage 2007 and ISI Impact Factor 2007. After tabulating the results for each discipline, the Pearson product-moment correlation coefficient was used to see whether the level of correlation between VUW usage statistics and ISI Impact Factor data in each discipline is significant, thereby answering sub question one:

Is there a statistically significant relationship between the VUW usage statistics and the ISI Impact Factor of a journal title? 
The Pearson product-moment correlation coefficient $(r)$ is a parametric test that indicates the strength of relationship between two variables (Hafner, 1998, 215):

$$
r=\frac{n \sum X Y-\sum X \sum Y}{\sqrt{ }\left\{\left[\sum \mathrm{X}^{2}-\left(\sum \mathrm{X}\right)^{2}\right]\left[\sum \mathrm{Y}^{2}-\left(\sum \mathrm{Y}\right)^{2}\right]\right\}}
$$

The Pearson product-moment correlation coefficient test describes the degree of linear correlation between two variables (Hernon, 1994, 159). As such, this is an appropriate test for analysing the correlation between ranked data. In the instance of a positive relationship, there may be a correlation between VUW usage statistics and ISI Impact Factor to enable it to be employed as a decision-making tool in collection management. Whether this should be the only decision-making tool used in collection management will be discussed further in the results.

To provide a more visual tool in analysing the level of correlation between VUW usage statistics and ISI Impact Factors, the tabulated results were plotted into a scatter graph identify any extreme results or points for discussion.

The steps above were repeated for each discipline and the results compared in order to answer sub question two:

Is there a statistically more significant correlation in a particular discipline than in another? 


\section{RESULTS}

VUW electronic journal usage data and ISI Impact Factors were collected for the journal titles included in the 10 disciplines listed in Figure 2. It was thought that the higher the number of platforms a title was available on may have had an impact upon the level of journal use. This did not appear to be a major factor in the level of use, although it could be an interesting topic of further research to analyse the levels of usage via different information provider's platforms.

It was interesting to note that although the information providers Oxford Journals and Oxford Journals Online were noted separately in the Journal Use Reports, the results were duplicated. For example, Figure 3 displays the usage data for the journal title Applied Linguistics:

Figure 3: VUW Usage Statistics by Information Provider for Applied Linguistics

\begin{tabular}{|l|l|l|l|}
\hline Journal Title & ISSN & Information Provider & $\begin{array}{l}\text { VUW Usage } \\
2007\end{array}$ \\
\hline Applied Linguistics & $0142-6001$ & EBSCO & 0 \\
& & Oxford Journals & 1082 \\
& & Oxford Journals Online & 1082 \\
& & ProQuest & 215 \\
\hline
\end{tabular}

This issue was found for all journal titles provided through Oxford Journals and Oxford Journals Online platforms. Where duplicate results were found, they were not included. Therefore, for this project the VUW usage for Applied Linguistics is 1297 rather than 2379 .

The data collection was limited by the providers included in the ISI Journal Citation Reports, as per Figure 4. 
Figure 4: Information Providers included in ISI's Journal Use Report

\begin{tabular}{|lll|}
\hline - ACS Digital Library & - Oxford Journals Online \\
- Annual Reviews & - Palgrave \\
- Blackwells Synergy & - Project Muse \\
- EBSCO & - ProQuest \\
- Emerald & - Royal Society of Chemistry \\
- HW Wilson & - Sage \\
- IEEE & - Science \\
- Index to Theses & - Science Present Classic \\
- JSTOR & - Science STKE \\
- Kluwer Journals Online & - ScienceDirect \\
- Nature & - ThomsonGale \\
\hline
\end{tabular}

This limitation affected the results with regard to New Zealand, and to a lesser extent, Australasian titles. The only identifiable New Zealand title was Political Science, included in the Journal Citation Reports for the Political Science discipline. Political Science was excluded from this study as it was not included in the Journal Use Report. The availability of New Zealand material in electronic format is a particular problem for New Zealand academic libraries. Many New Zealand publishers are too small to provide electronic access to their material themselves, and many larger information providers are unwilling to enter into time-consuming negotiations with smaller publishers for single or limited number of titles.

In spite of these issues, a number of information providers are starting to recognise the value of New Zealand scholarship and an increasing effort is being made to provide access to New Zealand material. The RMIT University (Melbourne, Australia) based Informit platform now includes a number of New Zealand journals in their Humanities \& Social Sciences Collection, for example New Zealand Journal of Environmental Law, New Zealand Research in Early Childhood Education and New Zealand Studies in Applied Linguistics. 
While the results of this project are skewed towards American and international titles due to the tools used and the lack of New Zealand material available electronically, it would be an interesting exercise to revisit this issue in a few years time and compare the levels of New Zealand electronic material available.

An interesting finding was that a number of titles appeared in two lists, particularly titles from the disciplines of Information Science \& Library Science, Economics, Management and Law. Although the usage data and the ISI Impact Factor was the same in each list, the number at which the title sat on each list differed considerably in some cases - see Figure 5. Although this issue is not part of this study, it could be an area for further research. 
Figure 5: Titles Appearing on Multiple Discipline Lists

\begin{tabular}{|c|c|c|c|c|}
\hline Journal Title \& Disciplines & ISSN & $\begin{array}{l}\text { VUW Usage } \\
\text { Statistics } \\
2007\end{array}$ & $\begin{array}{l}\text { ISI Impact } \\
\text { Factor } \\
2007\end{array}$ & $\begin{array}{l}\text { Number on } \\
\text { Discipline List }\end{array}$ \\
\hline $\begin{array}{l}\text { Information Systems Research } \\
\text { Information Science \& } \\
\text { Library Science } \\
\text { Management }\end{array}$ & $1047-7047$ & 354 & 2.682 & $\begin{array}{l}3^{\text {rd }} \\
8^{\text {th }}\end{array}$ \\
\hline $\begin{array}{l}\text { Journal of Management } \\
\text { Information Systems } \\
\text { Information Science \& } \\
\text { Library Science } \\
\text { Management }\end{array}$ & $0742-1222$ & 400 & 1.867 & $\begin{array}{l}5^{\text {th }} \\
17^{\text {th }}\end{array}$ \\
\hline $\begin{array}{l}\text { Information \& Management } \\
\text { Information Science \& } \\
\text { Library Science } \\
\text { Management }\end{array}$ & $0378-7206$ & 712 & 1.631 & $\begin{array}{l}8^{\text {th }} \\
22^{\text {nd }}\end{array}$ \\
\hline $\begin{array}{l}\text { Journal of Law \& Economics } \\
\text { Economics } \\
\text { Law }\end{array}$ & $0022-2186$ & 116 & 1.620 & $\begin{array}{l}19^{\text {th }} \\
22^{\text {nd }}\end{array}$ \\
\hline $\begin{array}{l}\text { Journal of Information } \\
\text { Technology } \\
\text { Information Science \& } \\
\text { Library Science } \\
\text { Management }\end{array}$ & $0268-3962$ & 206 & 1.605 & $\begin{array}{l}9^{\text {th }} \\
24^{\text {th }}\end{array}$ \\
\hline $\begin{array}{l}\text { Ecological Economics } \\
\text { Economics } \\
\text { Environmental Science }\end{array}$ & 0921-8009 & 1091 & 1.549 & $\begin{array}{l}23^{\text {rd }} \\
55^{\text {th }}\end{array}$ \\
\hline $\begin{array}{l}\text { Journal of Law Economics \& } \\
\text { Organization } \\
\text { Economics } \\
\text { Law }\end{array}$ & $8756-6222$ & 90 & 1.488 & $\begin{array}{l}27^{\text {th }} \\
26^{\text {th }}\end{array}$ \\
\hline $\begin{array}{l}\text { International Journal of } \\
\text { Forecasting } \\
\text { Economics } \\
\text { Management }\end{array}$ & $0169-2070$ & 29 & 1.409 & $\begin{array}{l}34^{\text {th }} \\
30^{\text {th }}\end{array}$ \\
\hline $\begin{array}{l}\text { Industrial \& Corporate Change } \\
\text { Economics } \\
\text { Management }\end{array}$ & $0960-6491$ & 117 & 1.325 & $\begin{array}{l}38^{\text {th }} \\
33^{\text {rd }}\end{array}$ \\
\hline $\begin{array}{l}\text { Journal of Economics \& } \\
\text { Management Strategy } \\
\text { Economics } \\
\text { Management } \\
\end{array}$ & $1058-6407$ & 41 & 0.875 & $\begin{array}{l}68^{\text {th }} \\
47^{\text {th }}\end{array}$ \\
\hline $\begin{array}{l}\text { Post-Soviet Affairs } \\
\text { Economics } \\
\text { Political Science }\end{array}$ & $1060-586 \mathrm{X}$ & 0 & 0.833 & $\begin{array}{l}73^{\text {rd }} \\
27^{\text {th }}\end{array}$ \\
\hline $\begin{array}{l}\text { Law Library Journal } \\
\text { Information Science \& } \\
\text { Library Science } \\
\text { Law }\end{array}$ & $0023-9283$ & 81 & 0.789 & $\begin{array}{l}24^{\text {th }} \\
57^{\text {th }}\end{array}$ \\
\hline $\begin{array}{l}\text { New Political Economy } \\
\text { Economics } \\
\text { Political Science } \\
\end{array}$ & $1356-3467$ & 74 & 0.702 & $\begin{array}{l}90^{\text {th }} \\
36^{\text {th }}\end{array}$ \\
\hline $\begin{array}{l}\text { Journal of Common Market } \\
\text { Studies } \\
\quad \text { Economics } \\
\text { Political Science }\end{array}$ & $0021-9886$ & 152 & 0.653 & $\begin{array}{l}97^{\text {th }} \\
39^{\text {th }}\end{array}$ \\
\hline $\begin{array}{l}\text { Chinese Law \& Government } \\
\text { Law } \\
\text { Political Science }\end{array}$ & $0009-4609$ & 0 & 0.091 & $\begin{array}{l}100^{\text {th }} \\
86^{\text {th }}\end{array}$ \\
\hline
\end{tabular}




\subsection{Faculty of Humanities and Social Science}

\section{History Discipline}

The ISI Journal Citation Report for History contained 17 titles, 16 of which were selected for data analysis - see Appendix 6.1. One title was excluded on the grounds that it did not appear in the ISI Journal Use Report following the project limitations listed in the methodology section above.

The level of correlation for the History titles was reasonable, with $r=0.569$. This was an interesting result as the number of titles available for analysis was the lowest of all disciplines studied. It is likely that this correlation result does not truly reflect the History discipline due to the limited number of titles included in the study. It was thought that History related titles may have been classified into other History related subject headings, such as American History, although this proved not to be the case.

\section{Figure 6: History Discipline - VUW Usage Statistics and ISI Impact} Factors

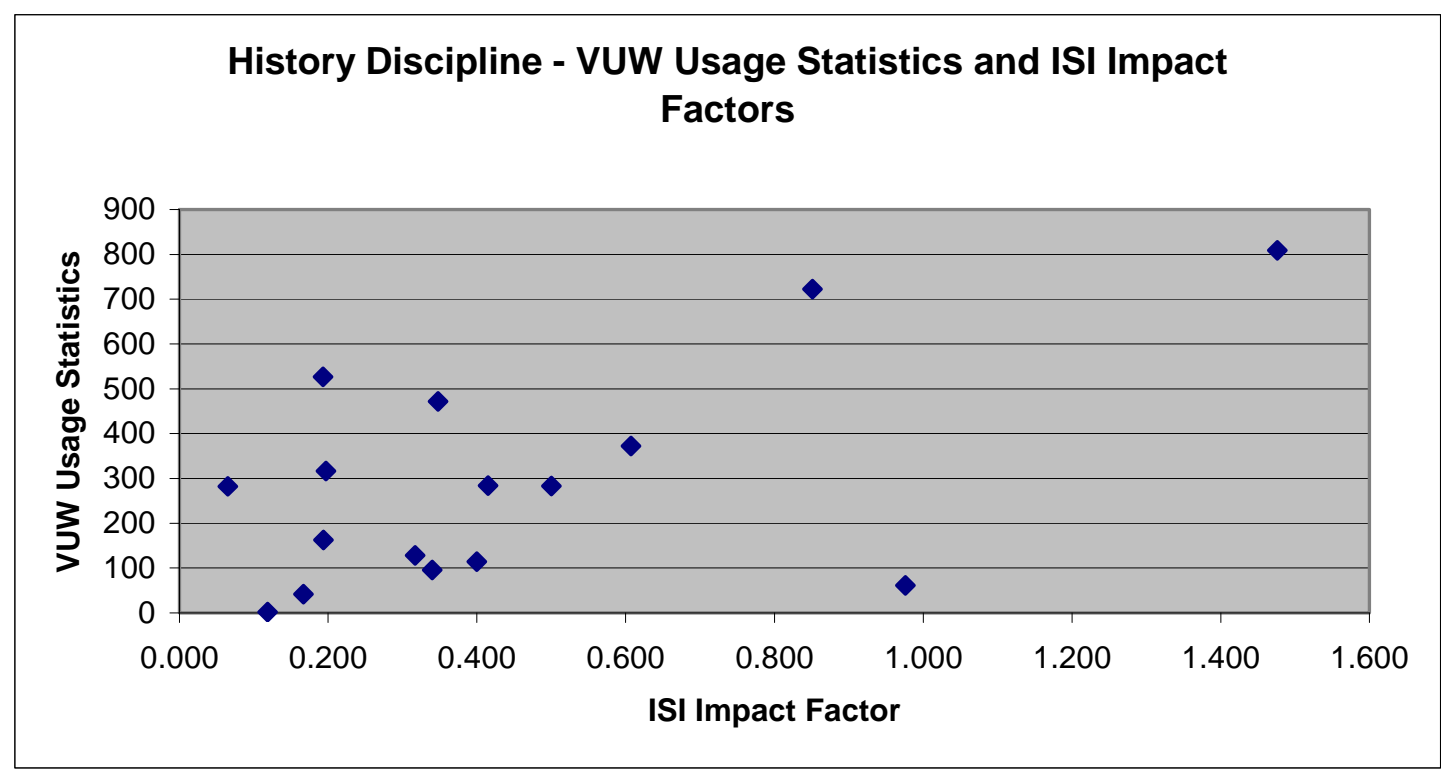

There is no identifiable reason for the outlying result for American Historical Review, which had an Impact Factor and usage of 809. The number of platforms the title was 
available on does not appear to be a factor, American Historical Review being available from three information providers, which is less than other titles further down the list, for example Journal of African History, with an Impact Factor of 0.500 and a usage of 283, was available on six platforms.

\section{Linguistics Discipline}

Of the 55 titles listed on the Linguistics Journal Citation Report, 47 titles were included in the data analysis - see Appendix 6.2. As per the project limitations, eight titles were excluded on the grounds that they did not appear in the Journal Use Report.

The results for the Linguistics titles showed a very small negative correlation with $r=$ -0.049. In Figure 7, three titles, Brain \& Language, Journal of Memory \& Language and Computational Linguistics had Impact Factors greater than 2.300. While the first two titles showed similar usage of 350 and 286 respectively, Computational Linguistics showed zero usage despite VUW subscribing to 1980-current via ACM Digital Library, a provider included in the Journal Use Reports. 
Figure 7: Linguistics Discipline - VUW Usage Statistics and ISI Impact Factors

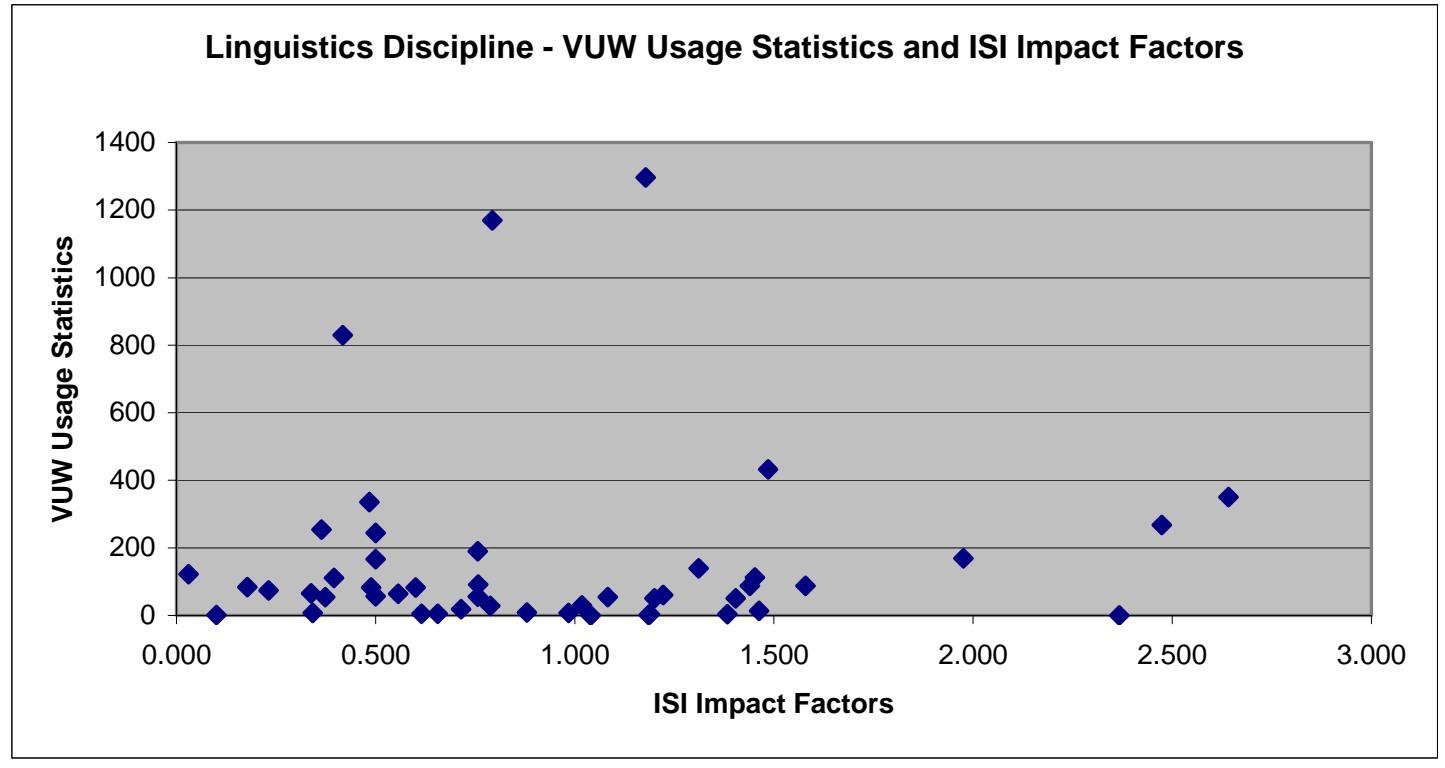

Figure 7 shows two titles with Impact Factors below 1.500, but with significantly higher usage than those titles mentioned above. Applied Linguistics and Modern Language Journal both had similar usage statistics of 1,297 and 1,170 respectively, but the Impact Factor was significantly different, 1.178 and 0.793 respectively. The similarity of usage may be attributable to each title being available via three information providers, but this does not hold true across the board. It is interesting that a number of titles show very low usage, regardless of the Impact Factor rating or the number of information providers providing access. For example, Modern Language Journal has an Impact Factor of 0.793 but a usage of 1,170, whereas a similar title Journal of Linguistics has an Impact Factor of 0.788 , but only 28 uses across three information providers.

\section{Political Science Discipline}

The Political Science Journal Citation Report listed 93 titles, 81 of which were included in this project - see Appendix 6.3. Twelve titles were excluded on the grounds that they did not appear in the ISI Journal Use Report. 
There was a low level of correlation for Political Science titles, with $r=0.331$. A factor in this could be the interdisciplinary nature of the discipline, with a mixture of international titles. Figure 8 illustrates the broad spread of data for Political Science. There does not seem to be an apparent reason for this spread. American Political Science has an Impact Factor of 2.317 and usage of 840, however Annals of the American Academy of Political Science \& Social Science has similar usage of 824, but an Impact Factor of 0.836. Similarly, Political Analysis shows usage of 5, but an Impact Factor of 2.535, higher than that of American Political Science.

\section{Figure 8: Political Science Discipline - VUW Usage Statistics and ISI Impact Factors}

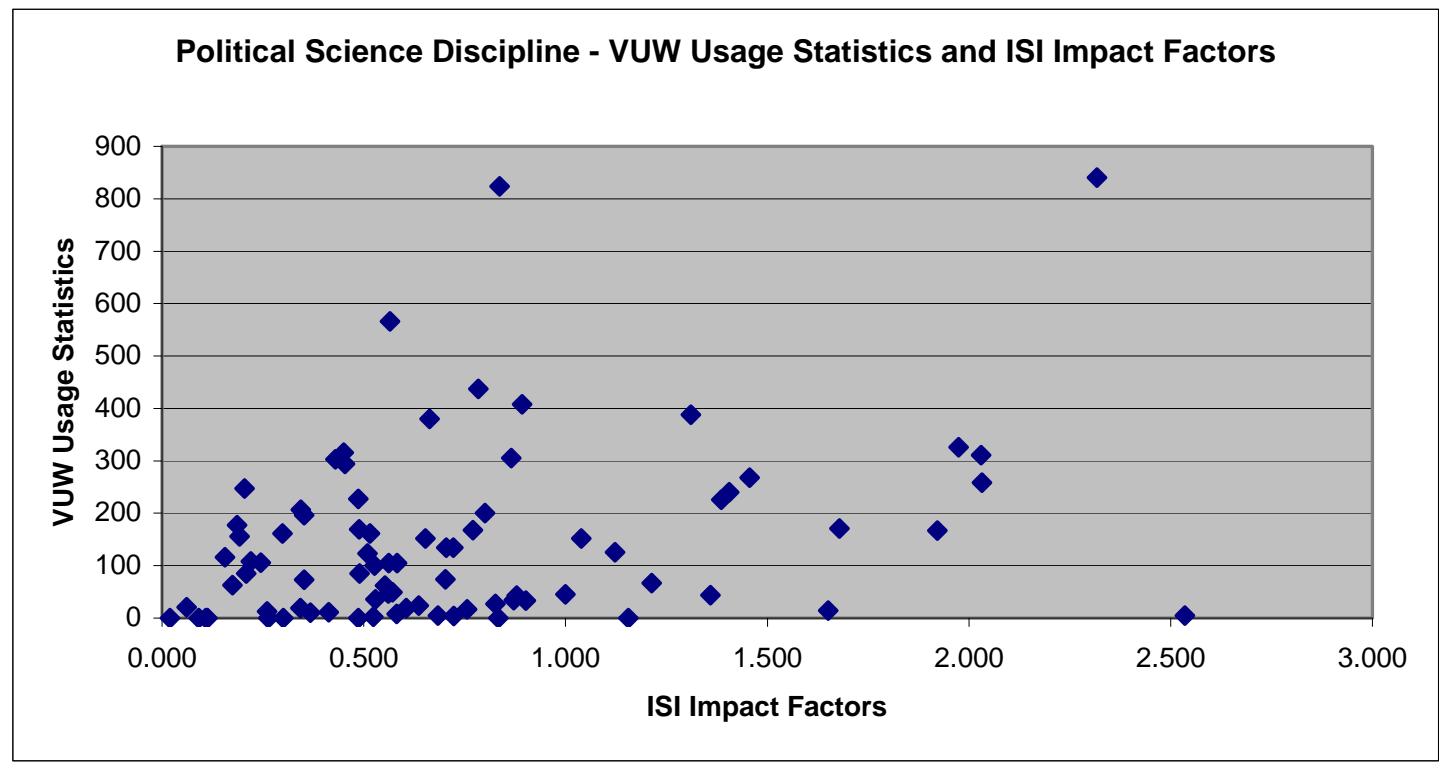

It is interesting to note that several journal titles with a very low Impact Factor also have a very low or zero usage, for example Russian Politics and Chinese Law \& Government. For these two titles, this could be attributed to the limited focus of the journal or differing research and teaching focuses at VUW. 


\subsection{Faculty of Science}

\section{Environmental Science Discipline}

The Journal Citation Report for Environmental Science contained 160 titles, the first 100 of which were used for data collection - see Appendix 6.4. Of the 100 titles, 19 titles were excluded as they did not appear on the Journal Use Report, leaving 81 titles for data analysis.

The level of correlation for Environmental Science titles was low, with $r=0.262$. A significant factor in the level of correlation may have been the extreme result of Environmental Science \& Technology with an Impact Factor of 4.363 and usage of 20,601 .

Figure 9a: Environmental Science Discipline - VUW Usage Statistics and ISI Impact Factors

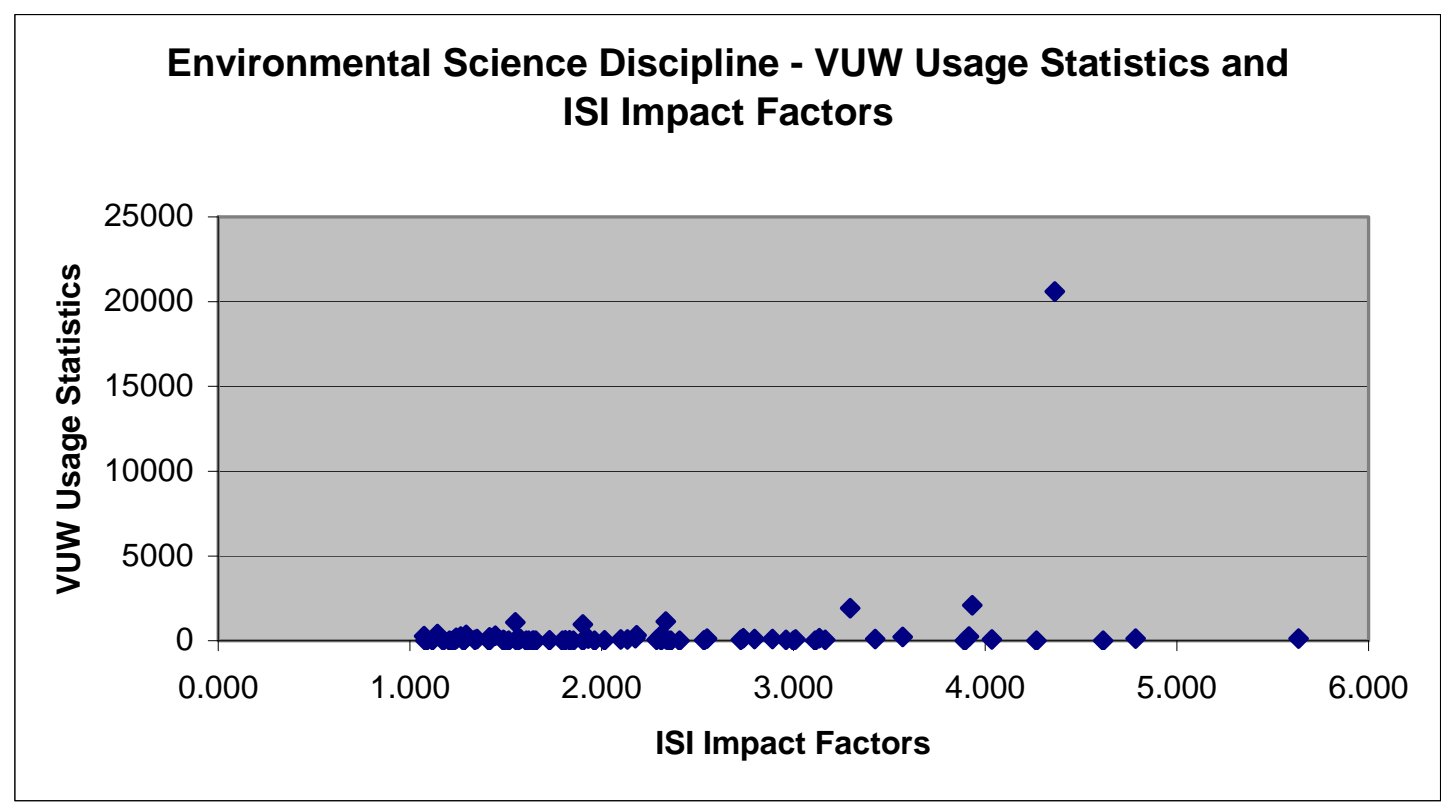


As the extreme result of Environmental Science \& Technology has skewed the results illustrated in Figure 9a, this value has been removed from Figure $9 \mathrm{~b}$ to better enable analysis of the data for the other titles.

Figure 9b: Environmental Science Discipline - VUW Usage Statistics and ISI Impact Factors - Adjusted

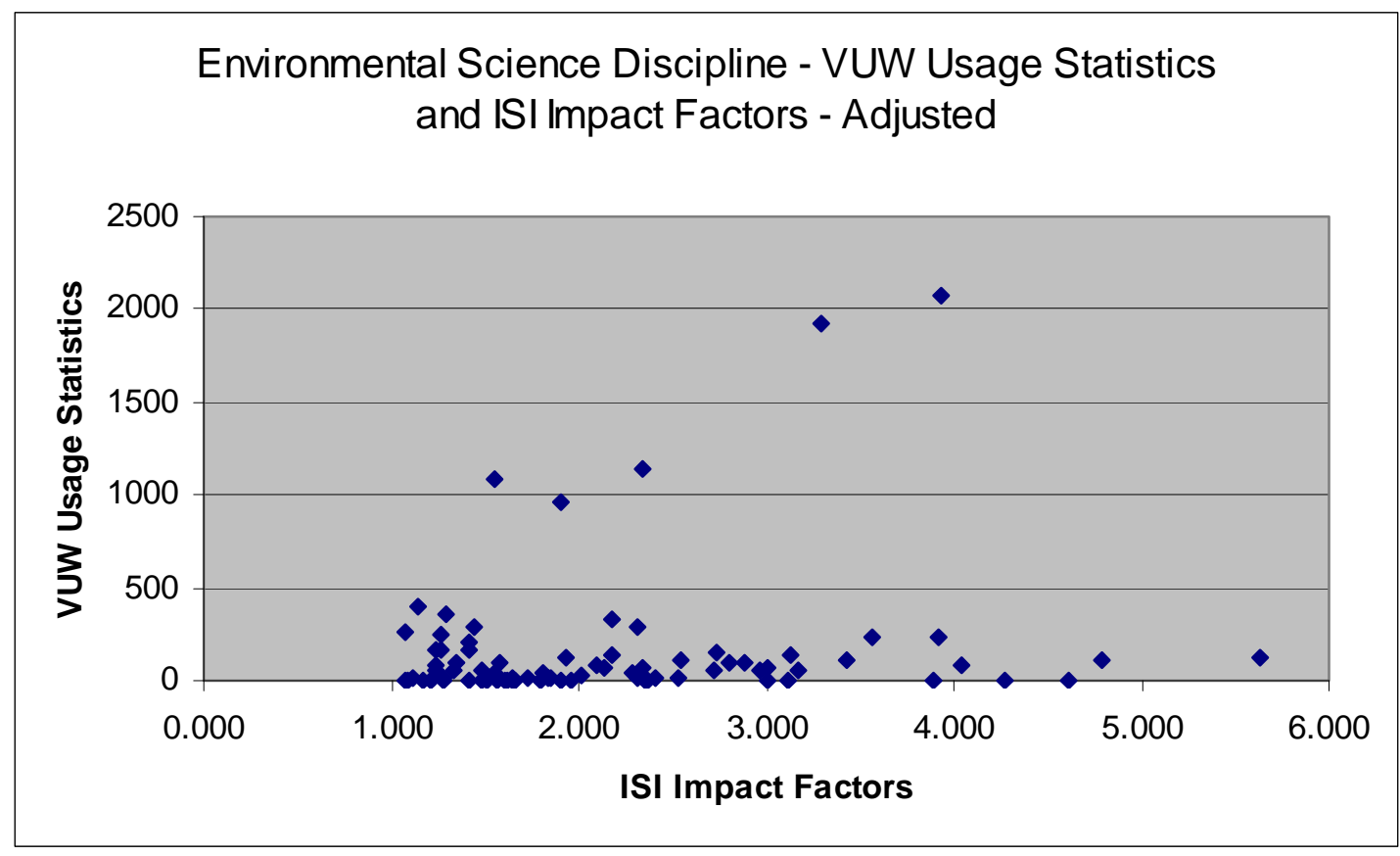

The journals included in the Environmental Science Journal Citation Report showed very good usage regardless of the Impact Factor rating. There were four journal titles that had usage results of more than 1,000 downloads: Conservation Biology with an Impact Factor of 3.934, Biological Conservation with an Impact Factor of 3.296, Marine Pollution Bulletin with an Impact Factor of 2.334 and Ecological Economics with an Impact Factor of 1.549. Most titles were only available from one information provider and this did not seem to affect the Impact Factor or usage statistics for the titles. 


\section{Mathematics Discipline}

Of the 207 titles listed in the Journal Citation Report for Mathematics, the first 100 were used in data collection as per the project limitations listed in the methodology section above - see Appendix 6.5. Of these 100 titles, 65 titles were included in data analysis, 35 titles being excluded on the grounds that they did not appear in the Journal Use Report. This is the largest number of titles in a single discipline that were excluded from this project.

Mathematics had a very low negative correlation, with $r=-0.072$. Only two titles had usage results over 80, Journal of Algebra and Journal of Symbolic Logic, with Impact Factors of 0.630 and 0.609 respectively.

Figure 10: Mathematics Discipline - VUW Usage Statistics and ISI Impact Factors

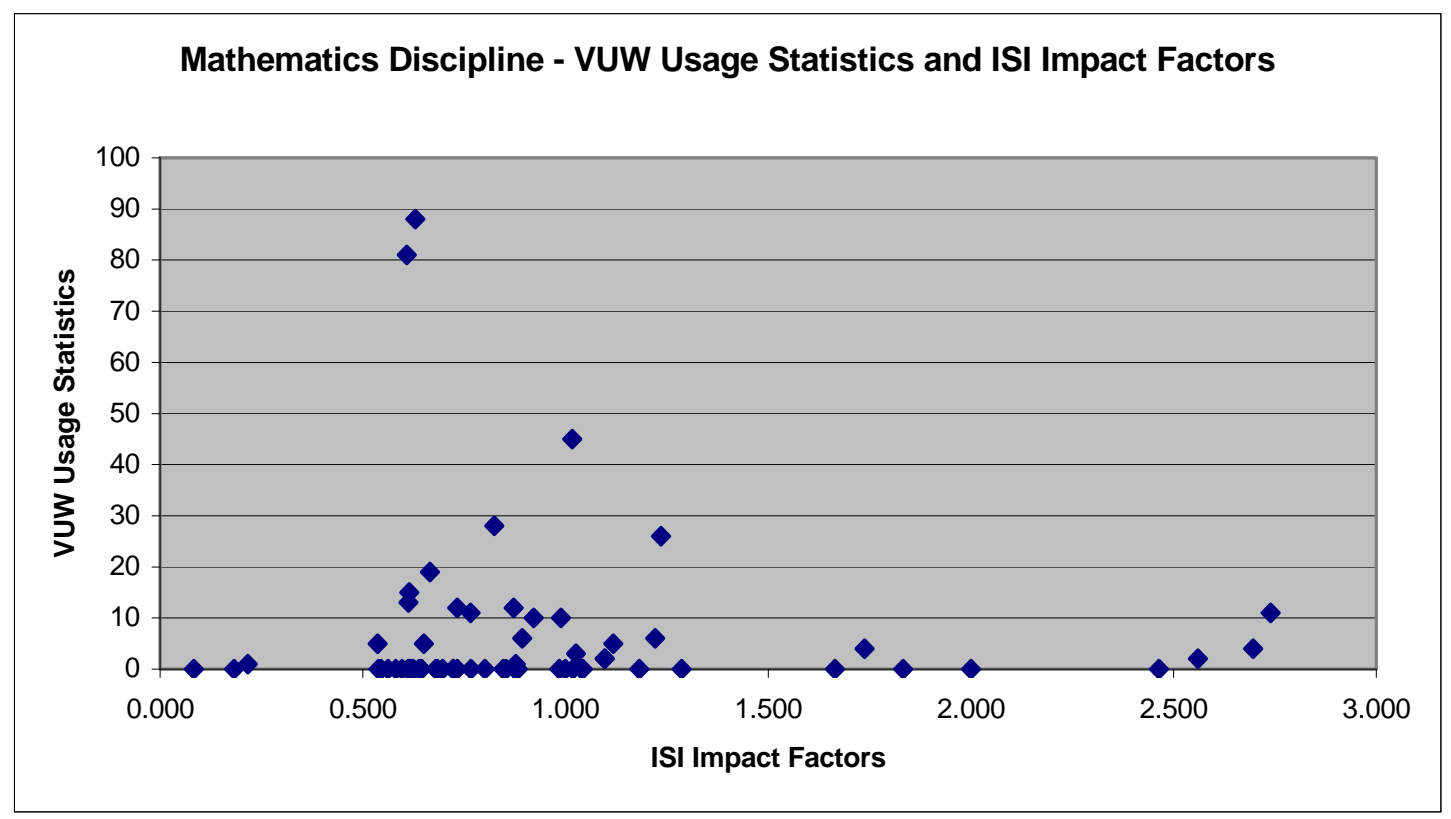

This discipline had the highest number of titles with zero usage, which may be a factor in the low correlation. This result may indicate that this discipline has a higher number of journal titles outside the research and teaching focus of VUW. 


\section{Physics (Applied) Discipline}

The Journal Citation Report for Physics (Applied) contained 94 titles, 64 of which were selected for data analysis - see Appendix 6.6. Thirty titles were excluded on the grounds that they did not appear in the Journal Use Report as per the project limitations noted above.

The level of correlation for Physics (Applied) was reasonable, with $r=0.434$. This is an interesting result considering the high number of zero usage results in the data. Like the results for Mathematics, Physics (Applied) had a large number of excluded titles and a large number of zero usage results. This could indicate that the focus of research and teaching at VUW differs from the titles listed in the Journal Citation Reports. That such a large number of journal titles appear not to be being used in electronic format may be worthy of further investigation.

\section{Figure 11: Physics (Applied) - VUW Usage Statistics and ISI Impact Factors}

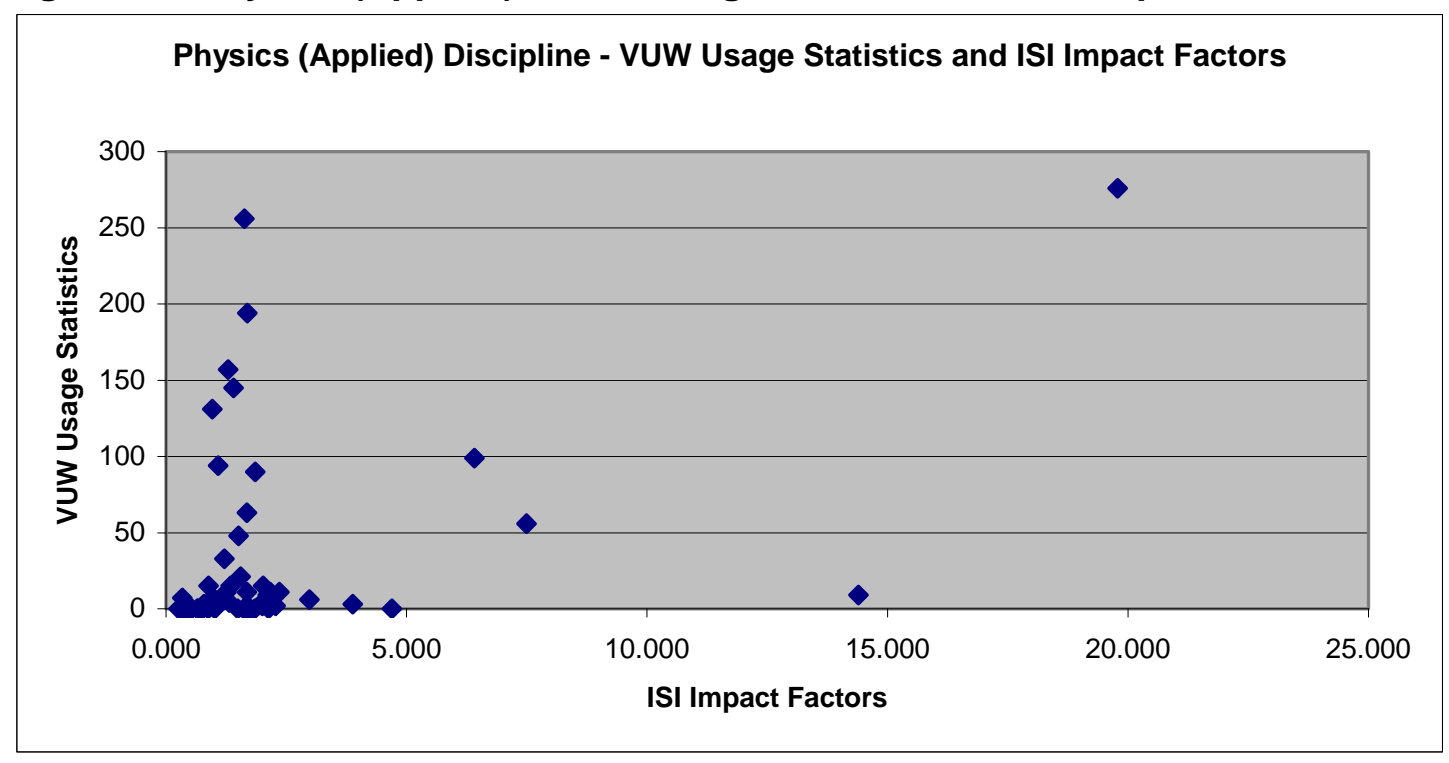

Nature Materials had a very high Impact Factor rating of 19.782 and the highest usage of 276. This title was followed closely by Materials Science \& Engineering Reports with an Impact Factor of 14.400, but a usage of only 9. There was an 
interesting trend for low Impact Factor journals to achieve some of the highest ratings within the discipline, for example, Thin Solid Films, Materials Letters, and Applied Surface Science with usage of 194, 256 and 145 respectively. The Impact Factors for these titles are similar, being $1.693,1.625$ and 1.406 respectively.

\subsection{Faculty of Commerce \& Administration}

\section{Economics Discipline}

Of the 191 titles in the Journal Citation Report for Economics, the first 100 titles were used in data collection - see Appendix 6.7. From the 100 titles, 99 were selected for data analysis. One title was excluded on the grounds that it did not appear in the ISI Journal Use Report. This was the best result in terms of the number of titles selected for inclusion in this project.

There was a low level of correlation for the Economics discipline, with $r=0.230$. There is a significant cluster of titles with Impact Factors between 0.500 and 1.000 and with usage between zero and 200. Three titles had Impact Factors above 3.500, Journal of Political Economy with an Impact Factor of 4.190, Journal of Economic Literature with an Impact Factor of 3.973 and Quarterly Journal of Economics with an Impact Factor of 3.688. 
Figure 12: Economics Discipline - VUW Usage Statistics and ISI Impact Factors

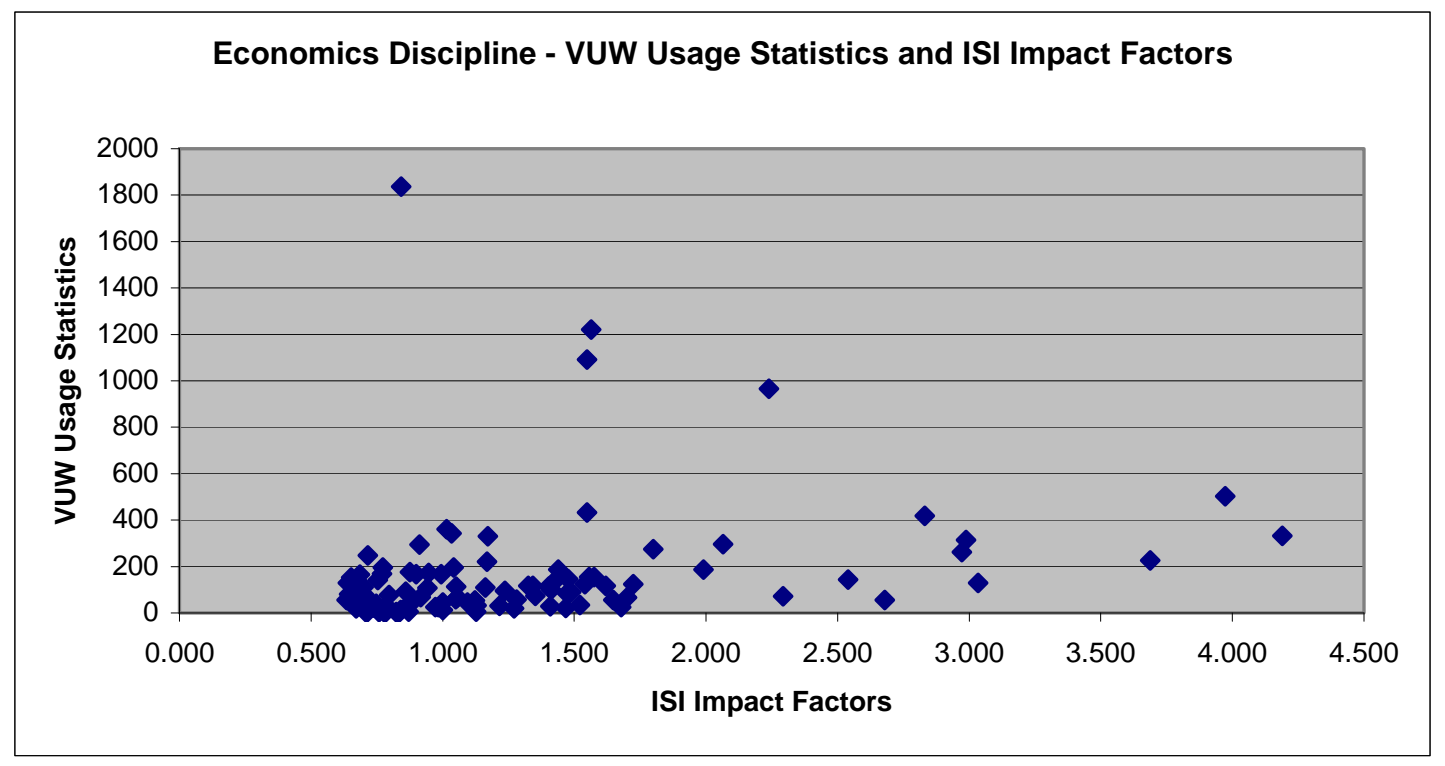

While the usage for these titles was reasonable, other titles with smaller Impact Factors achieved greater usage statistics. The Journal of World Development had usage of 1,221, Ecological Economics 1,091 and Futures 1,837. The Impact Factors for these three titles were reasonably low, $1.565,1.549$ and 0.843 respectively. The high usage results could be the result of the more interdisciplinary nature of the titles compared to titles with lower usage results.

\section{Information Science \& Library Science Discipline}

The Journal Citation Report for Information Science \& Library Science contained 56 titles, 48 of which were included for data analysis - see Appendix 6.8. Eight titles were excluded as they did not appear in the Journal Use Report as per the limitations listed in the methodology section above. 
There was a low level correlation of $r=0.137$ for Information Science \& Library

Science. There were very few titles with usage values under 30 , and only one title with a usage value of one. The majority of results appear between Impact Factor ratings 0.000 and 1.500 , and usage values of 0 to 500 . This is one of the most closely bunched results from all disciplines studied.

Figure 13: Information Science \& Library Science Discipline - VUW Usage Statistics and ISI Impact Factors

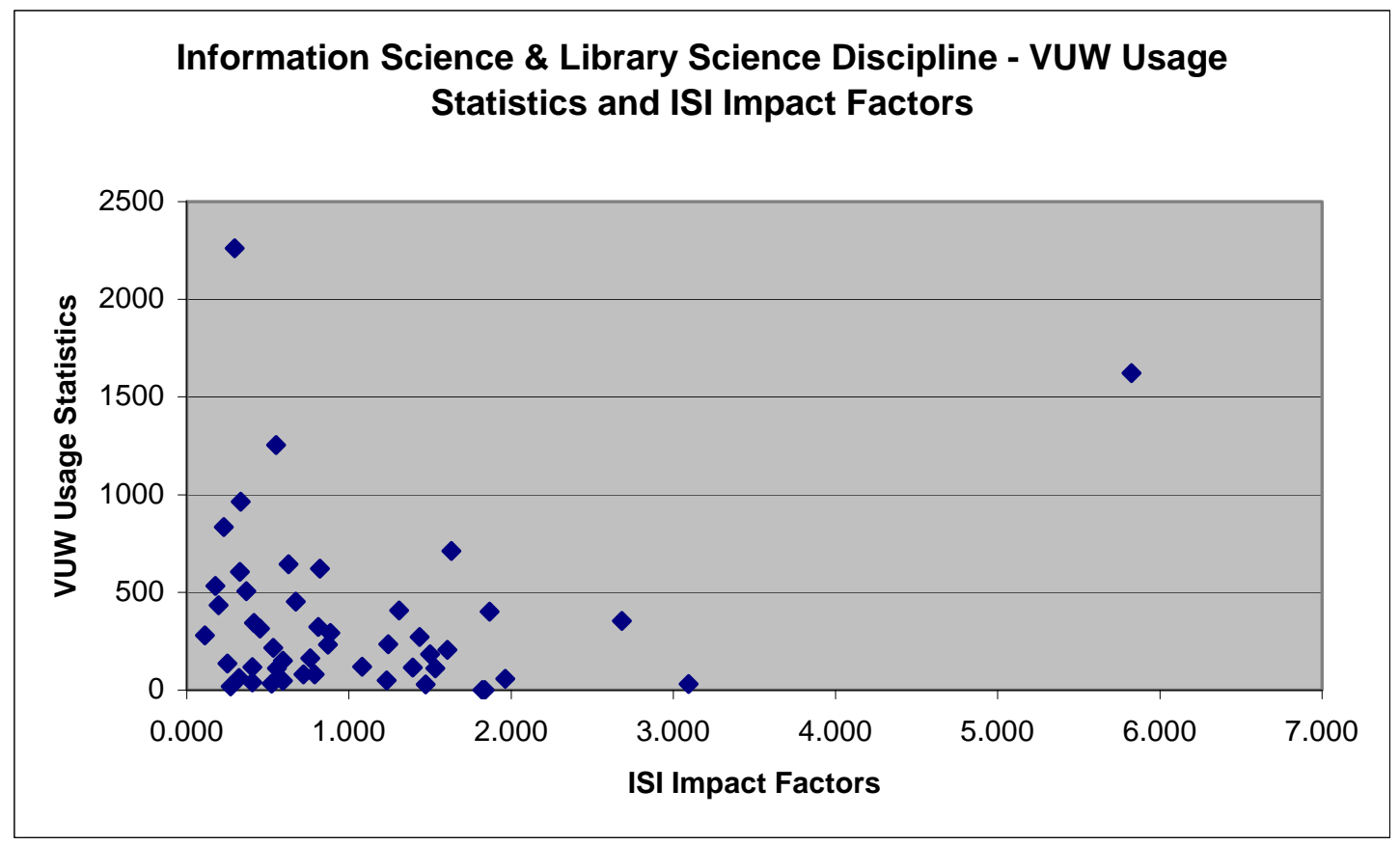

The journal title MIS Quarterly had the highest Impact Factor rating in the discipline of 5.826, and a reasonable usage value of 1,623 . The only other title with a higher usage value was Library Journal with 2,261. However, this title had one of the lowest Impact Factor ratings in the discipline, 0.295. 


\section{Management Discipline}

Of the 81 titles contained in the Journal Citation Report for Management, 79 titles were selected for data analysis - see Appendix 6.9. Only two titles were excluded for not appearing in the Journal Use Report.

The Management discipline had a reasonable positive correlation, with $r=0.412$. The majority of data appears between the Impact Factor ratings of 0.300 and 1.500 and between usage values of 0 and 400 . Few titles break this mould, with only three titles with Impact Factors greater than 4.000, MIS Quarterly with an Impact Factor of 5.826, The Academy of Management Journal with an Impact Factor of 5.017 and The Academy of Management Review with an Impact Factor of 4.372.

\section{Figure 14: Management Discipline - VUW Usage Statistics and ISI Impact} Factors

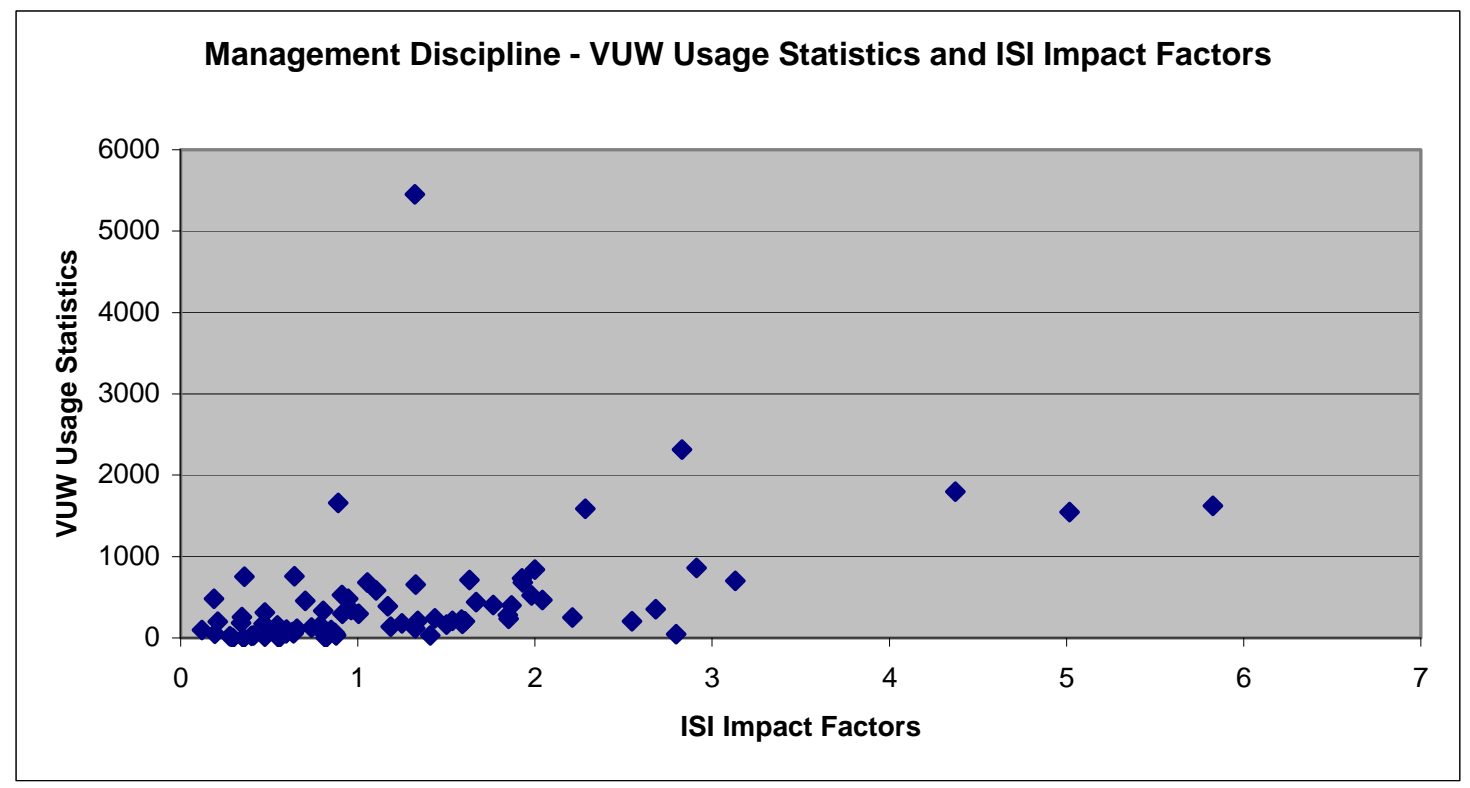

The highest usage value in the data was 5,452 for Harvard Business Review.

Although this journal has a reasonably low Impact Factor of 1.323 , it does sit in the upper half of the results. The Harvard Business Review was available through four 
information providers, though this does not seem to be a factor in the high usage value.

\subsection{Faculty of Law}

\section{Law Discipline}

The Journal Citation Report for Law contained 101 titles, the first 100 of which were used for data collection - see Appendix 6.10. Thirty-two titles were excluded from this project on the grounds that they did not appear in the ISI Journal Use Report as per the limitations of this project.

There was a low positive correlation for the Law discipline, with $r=0.370$. There are a number of titles with little or no usage between the Impact Factor ratings of 0.000 and 1.000. These titles tend to relate to law and medicine, family law, maritime law, and European law. It could be that these subject areas within the Law discipline are not widely studied at VUW.

Figure 15: Law Discipline - VUW Usage Statistics and ISI Impact Factors

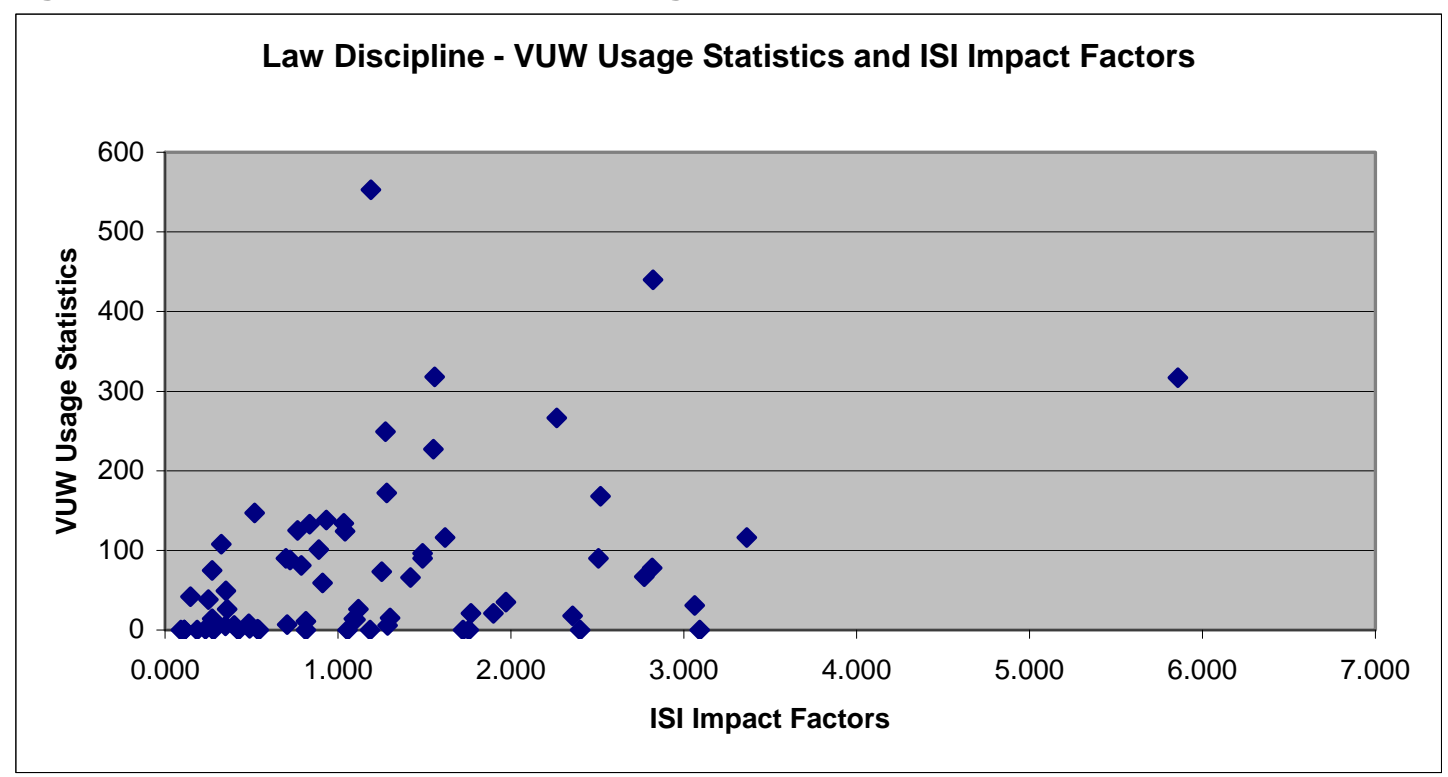


There were two titles with usage values over 400, The American Journal of International Law with a usage value of 553 and The Yale Law Journal with a usage value of 440. The Impact Factors of these journals were 1.191 and 2.821 respectively. Harvard Law Review was the journal with the highest Impact Factor of 5.859, however its usage was considerably lower than that of The American Journal of International Law and The Yale Law Journal. It is interesting to note that the highest used journal was an international title. 


\section{CONCLUSION}

The level of correlation between usage statistics for electronic journals at Victoria University of Wellington Library and the journal rankings produced by ISI were less than anticipated. Although there is a small correlation between the VUW usage statistics and the ISI Impact Factor for several disciplines included in this study, these results are not common across all disciplines. Eight out of ten disciplines studies showed a positive correlation, however only three disciplines showed a positive correlation of more than 4.000, History, Physics (Applied) and Management.

As noted above, it is interesting that History, an area not well covered by the Journal Citation Reports, should show the highest level of correlation. It is unlikely that this level of correlation is a true reflection of the level of correlation in the History discipline due to the small number of titles included in this study. Of course, having fewer key titles in an area increases the likelihood of an institution not only subscribing, but using those titles.

Figure 16: Summary of Correlation Levels by Faculty and Discipline

\begin{tabular}{|l|c|}
\hline Faculty \& Discipline & $\begin{array}{l}\text { Correlation } \\
\text { Level }\end{array}$ \\
\hline Faculty of Humanities \& Social Sciences & \\
History & 0.569 \\
Linguistics & -0.049 \\
Political Science & 0.331 \\
\hline Faculty of Science & \\
Environmental Science & 0.262 \\
Mathematics & -0.072 \\
Physics (Applied) & 0.434 \\
\hline Faculty of Commerce \& Administration & \\
Economics & 0.230 \\
Information Science \& Library Science & 0.137 \\
Management & 0.412 \\
\hline Faculty of Law & 0.370 \\
Law & \\
\hline
\end{tabular}


Two disciplines showed a small negative correlation, Linguistics and Mathematics. While the high levels of zero usage for Mathematics may have been a factor in the result, this does not appear to have been a factor for Linguistics. Differences in research, teaching and learning areas within each discipline may be another factor in the result. In the Linguistics discipline, titles relating to brain, memory and language and second language acquisition were used more frequently than those relating to language disorders or child language.

There does not appear to be a statistically more significant correlation in a particular faculty than in another. The Faculty of Law showed the highest level of correlation, although only one discipline was included in this faculty. The Faculty of Humanities \& Social Sciences has a similar level of correlation to that of the Faculty of Law; however within the Faculty there were significant differences in the levels of correlation between disciplines.

A total of 648 journal titles were included in this study. The level of correlation across all titles was low, with $r=0.138$. Figure 17 illustrates the spread for all titles studied. Although some individual disciplines showed a higher level of correlation than others, with all titles taken as a whole, the level of correlation is slight. 
Figure 17: All Disciplines - VUW Usage Statistics and ISI Impact Factors

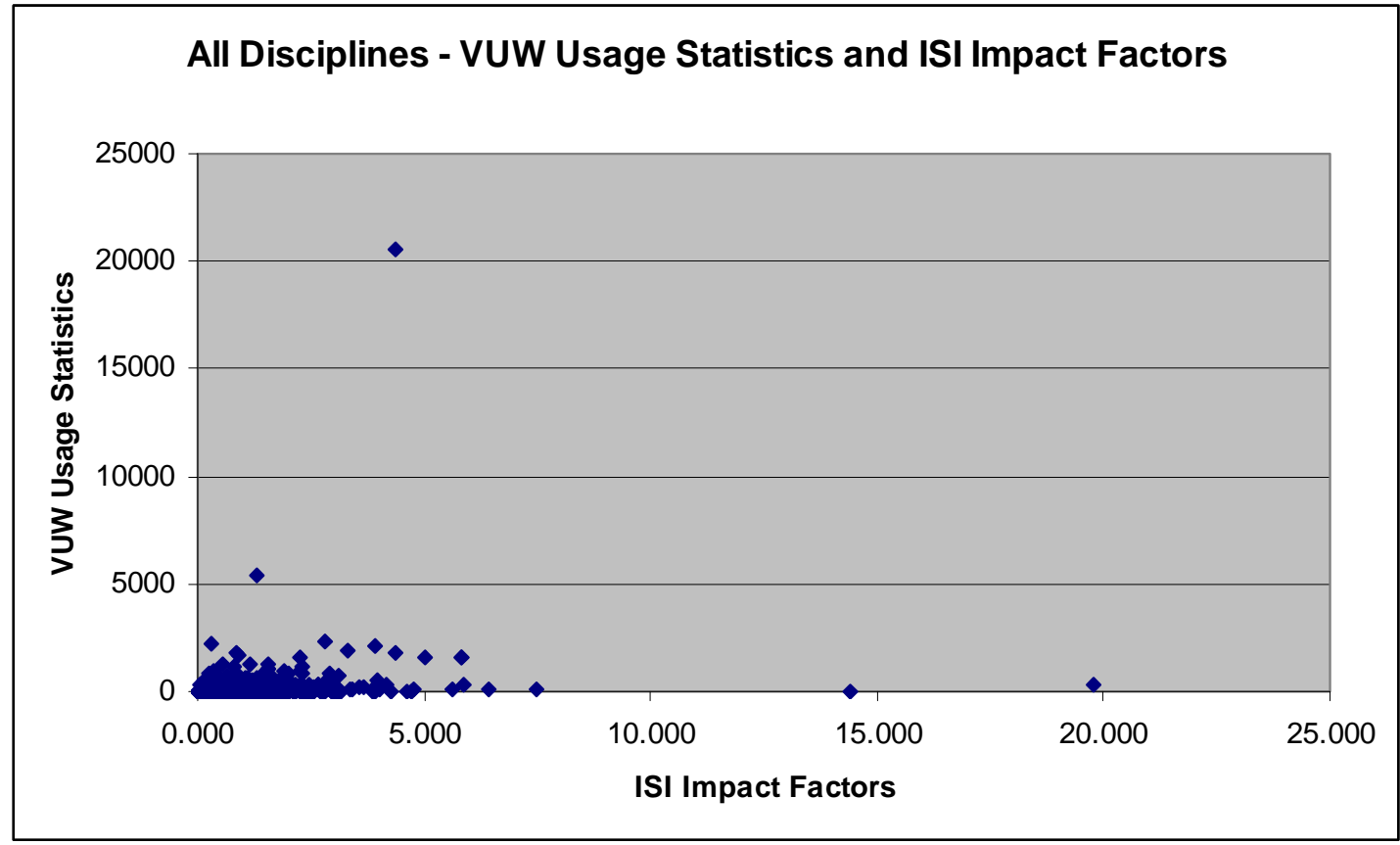

There were a number of reasons identified throughout this study that could have impacted upon the levels of correlation found in the disciplines:

- The ease of downloading journal articles could mean that articles are being downloaded for a cursory glance rather than for intended use

- The limited number of titles subscribed to by VUW

- The lack of New Zealand and Australasian title representation on the Journal Citation Reports and Journal Use Report

- The interdisciplinary nature or limited focus of some journal titles

- The focus of research, teaching and learning within a discipline

While further study of whether these issues were significant factors in the levels of correlation between VUW electronic journal usage and ISI Impact Factor is outside the bounds of this project, these issues may be of interest for further research. 
While significant levels of correlation were found for some disciplines, other disciplines showed little positive correlation or a negative correlation. Although there were a number of reasons identified as possible factors in the correlation levels, the levels themselves were not of such a significance to enable ISI Impact Factors to be used in isolation as an effective collection management decision-making tool.

The authors experience indicates that there are a number of tools used in collection management for journal evaluation and decision-making processes. One of the most important considerations in journal evaluation is content. This includes the coverage of unique material, often from a New Zealand or Australasian perspective. The number of holding libraries for a resource is also a consideration, particularly for a marginal area of study. Whether a member of the institution is part of an editorial board, uses the journal for publishing their own articles, as well as resource review and citation-based ranking tools can influence the decision-making process.

Budget and access are increasing concerns for academic libraries, especially with regard to electronic material. The cost of an item, along with the availability of consortial discounts should be a consideration. Access issues are often closely related to the cost of providing resources. Price models are available for single or simultaneous access, and perpetual access is often preferred over a subscription model.

Impact Factors and other citation-based ranking tools are some of the evaluation options available to the academic library, but no tool should be used in isolation. 
The use of Impact Factors as a collection management evaluation tool continues to be an area of interest to academic researchers. Throughout this study, a number of issues were noted for further research. The relationship between electronic journal use and other journal-ranking tools needs further investigation. The level of use a patron makes of a downloaded electronic article is also of interest - what is the level of downloaded articles that are used in research, teaching, read to increase knowledge or not used at all? Additionally, an analysis of the variances in Impact Factors and usage by information platform would be useful for future collection development and management. 


\section{APPENDIXES}

Appendix 6.1: History Discipline - VUW Usage Statistics and ISI Impact Factors

\begin{tabular}{|l|l|r|r|}
\hline & & \multicolumn{1}{l}{$\begin{array}{l}\text { VUW } \\
\text { Usage } \\
\text { Journal Title }\end{array}$} & \multicolumn{2}{l}{$\begin{array}{l}\text { ISI Impactor } \\
\text { ISSN }\end{array}$} \\
\hline American Historical Review & $0002-8762$ & 809 & 1.476 \\
\hline Environmental History & $1084-5453$ & 61 & 0.976 \\
\hline Journal of American History & $0021-8723$ & 723 & 0.851 \\
\hline Past \& Present & $0031-2746$ & 372 & 0.607 \\
\hline Journal of African History & $0021-8537$ & 283 & 0.500 \\
\hline Journal of Modern History & $0022-2801$ & 284 & 0.415 \\
\hline Ethnohistory & $0014-1801$ & 114 & 0.400 \\
\hline Journal of Social History & $0022-4529$ & 472 & 0.348 \\
\hline History Workshop Journal & $1363-3554$ & 96 & 0.340 \\
\hline Social Science History & $0145-5532$ & 128 & 0.317 \\
\hline Comparative Studies in Society and & & & 0.197 \\
\hline History & $0010-4175$ & 317 & 0.194 \\
\hline Journal of the History of Sexuality & $1043-4070$ & 163 & 0.193 \\
\hline English Historical Review & $0013-8266$ & 527 & 0.167 \\
\hline International Review of Social History & $0020-8590$ & 42 & 0.119 \\
\hline Mouvement Social & $0027-2671$ & 2 & 0.065 \\
\hline Journal of Interdisciplinary History & $0022-1953$ & 282 & \\
\hline
\end{tabular}


Appendix 6.2: Linguistics Discipline - VUW Usage Statistics and ISI Impact Factors

\begin{tabular}{|c|c|c|c|}
\hline Journal Title & ISSN & $\begin{array}{l}\text { VUW } \\
\text { Usage } \\
2007 \\
\end{array}$ & $\begin{array}{l}\text { ISI Impact } \\
\text { Factor } \\
2007\end{array}$ \\
\hline Brain \& language & 0093-934X & 350 & 2.641 \\
\hline Journal of Memory \& Language & 0749-596X & 268 & 2.474 \\
\hline Computational Linguistics & 0891-2017 & 0 & 2.367 \\
\hline Language & 0097-8507 & 169 & 1.976 \\
\hline Applied Psycholinguistics & $0142-7164$ & 88 & 1.580 \\
\hline $\begin{array}{l}\text { Studies in Second Language } \\
\text { Acquisition }\end{array}$ & $0272-2631$ & 433 & 1.485 \\
\hline Linguistic Inquiry & 0024-3892 & 13 & 1.462 \\
\hline $\begin{array}{l}\text { Journal of Speech, Language \& } \\
\text { Hearing Research }\end{array}$ & $1092-4388$ & 112 & 1.452 \\
\hline Journal of Phonetics & $0095-4470$ & 88 & 1.439 \\
\hline $\begin{array}{l}\text { Language Speech \& Hearing Services } \\
\text { in Schools }\end{array}$ & $0161-1461$ & 51 & 1.404 \\
\hline Language \& Cognitive Processes & 0169-0965 & 4 & 1.383 \\
\hline Mind \& Language & $0268-1064$ & 139 & 1.311 \\
\hline Language Learning \& Technology & $1094-3501$ & 61 & 1.222 \\
\hline Journal of Neurolinguistics & 0911-6044 & 50 & 1.200 \\
\hline Journal of Fluency Disorders & 0094-730X & 4 & 1.188 \\
\hline $\begin{array}{l}\text { Research on Language and Social } \\
\text { Interaction }\end{array}$ & $0835-1813$ & 1 & 1.185 \\
\hline Applied Linguistics & $0142-6001$ & 1297 & 1.178 \\
\hline Journal of Communication Disorders & $0021-9924$ & 54 & 1.083 \\
\hline Metaphor \& Symbol & $1092-6488$ & 0 & 1.040 \\
\hline $\begin{array}{l}\text { American Journal of Speech - } \\
\text { Language Pathology }\end{array}$ & $1058-0360$ & 30 & 1.018 \\
\hline $\begin{array}{l}\text { International Journal of Language \& } \\
\text { Communication Disorders }\end{array}$ & $1368-2822$ & 7 & 0.984 \\
\hline Journal of Child Language & 0305-0009 & 9 & 0.880 \\
\hline Modern Language Journal & 0026-7902 & 1170 & 0.793 \\
\hline Journal of Linguistics & $0022-2267$ & 28 & 0.788 \\
\hline Language \& Speech & $0023-8309$ & 91 & 0.757 \\
\hline Bilingualism: Language \& Cognition & $1366-7289$ & 55 & 0.756 \\
\hline English for Specific Purposes & 0889-4906 & 190 & 0.756 \\
\hline Natural Language \& Linguistic Theory & 0167-806X & 19 & 0.714 \\
\hline Second Language Research & $0267-6583$ & 5 & 0.656 \\
\hline Clinical Linguistics \& Phonetics & $0269-9206$ & 5 & 0.615 \\
\hline $\begin{array}{l}\text { Journal of Language \& Social } \\
\text { Psychology }\end{array}$ & $0261-927 X$ & 82 & 0.600 \\
\hline Lingua & 0024-3841 & 64 & 0.556 \\
\hline Journal of Psycholinguistic Research & 0090-6905 & 57 & 0.500 \\
\hline Journal of Second Language Writing & $1060-3743$ & 166 & 0.500 \\
\hline Journal of Sociolinguistics & $1360-6441$ & 244 & 0.500 \\
\hline Language \& Communication & 0271-5309 & 83 & 0.488 \\
\hline Journal of Pragmatics & $0378-2166$ & 335 & 0.484 \\
\hline Language Learning & $0023-8333$ & 830 & 0.417 \\
\hline Language in Society & $0047-4045$ & 111 & 0.395 \\
\hline Language Sciences & 0388-0001 & 54 & 0.373 \\
\hline Foreign Language Annals & $0015-718 X$ & 254 & 0.364 \\
\hline International Journal of Lexicography & $0950-3846$ & 7 & 0.342 \\
\hline $\begin{array}{l}\text { Linguistics: an Interdisciplinary } \\
\text { Journal of the Language Sciences }\end{array}$ & 0024-3949 & 65 & 0.338 \\
\hline
\end{tabular}




\begin{tabular}{|l|l|r|r|}
\hline American Speech & $0003-1283$ & 74 & 0.231 \\
\hline $\begin{array}{l}\text { Canadian Modern Language Review/ } \\
\text { La Revue Canadienne des Langues } \\
\text { Vivantes }\end{array}$ & & & \\
\hline Journal of East Asian linguistics & $0008-4506$ & 84 & 0.178 \\
\hline Hispania & $0925-8558$ & 1 & 0.100 \\
\hline
\end{tabular}


Appendix 6.3: Political Science Discipline - VUW Usage Statistics and ISI Impact Factors

\begin{tabular}{|c|c|c|c|}
\hline Journal Title & ISSN & $\begin{array}{l}\text { VUW } \\
\text { Usage } \\
2007\end{array}$ & $\begin{array}{l}\text { ISI Impact } \\
\text { Factor } \\
2007\end{array}$ \\
\hline Political Analysis & $1047-1987$ & 5 & 2.535 \\
\hline American Political Science Review & $0003-0554$ & 840 & 2.317 \\
\hline American Journal of Political Science & $0092-5853$ & 258 & 2.032 \\
\hline Public Opinion Quarterly & $0033-362 X$ & 311 & 2.030 \\
\hline Journal of Conflict Resolution & $0022-0027$ & 326 & 1.975 \\
\hline Political Geography & 0962-6298 & 167 & 1.922 \\
\hline European Journal of Political Research & $0304-4130$ & 171 & 1.679 \\
\hline European Union Politics & $1465-1165$ & 14 & 1.651 \\
\hline Journal of Politics & $0022-3816$ & 268 & 1.456 \\
\hline Political Psychology & $0162-895 \mathrm{X}$ & 240 & 1.405 \\
\hline International Studies Quarterly & $0020-8833$ & 226 & 1.386 \\
\hline Annual Review of Political Science & 1094-2939 & 44 & 1.359 \\
\hline British Journal of Political Science & $0007-1234$ & 388 & 1.311 \\
\hline Comparative Political Studies & $0010-4140$ & 67 & 1.213 \\
\hline New Left Review & $0028-6060$ & 0 & 1.156 \\
\hline Electoral Studies & $0261-3794$ & 126 & 1.123 \\
\hline Political Communication & $1058-4609$ & 152 & 1.039 \\
\hline $\begin{array}{l}\text { Review of International Political } \\
\text { Economy }\end{array}$ & 0969-2290 & 45 & 1.000 \\
\hline Politics \& Society & 0032-3292 & 33 & 0.902 \\
\hline Journal of Peace Research & $0022-3433$ & 408 & 0.892 \\
\hline Political Behavior & 0190-9320 & 43 & 0.879 \\
\hline Journal of Theoretical Politics & 0951-6298 & 34 & 0.872 \\
\hline $\begin{array}{l}\text { Governance: An International Journal } \\
\text { of Policy \& Administration }\end{array}$ & $0952-1895$ & 305 & 0.865 \\
\hline $\begin{array}{l}\text { Annals of the American Academy of } \\
\text { Political and Social Science }\end{array}$ & $0002-7162$ & 824 & 0.836 \\
\hline Post-Soviet Affairs & $1060-586 X$ & 0 & 0.833 \\
\hline Legislative Studies Quarterly & $0362-9805$ & 27 & 0.826 \\
\hline Party Politics & $1354-0688$ & 200 & 0.800 \\
\hline Political Science Quarterly & $0032-3195$ & 437 & 0.784 \\
\hline Europe-Asia Studies & 0966-8136 & 168 & 0.770 \\
\hline Environmental Politics & 0964-4016 & 17 & 0.756 \\
\hline American Politics Research & $1532-673 X$ & 4 & 0.723 \\
\hline Publius: The Journal of Federalism & $0048-5950$ & 134 & 0.722 \\
\hline West European Politics & $0140-2382$ & 134 & 0.704 \\
\hline New Political Economy & $1356-3467$ & 74 & 0.702 \\
\hline Survival & 0039-6338 & 5 & 0.684 \\
\hline Journal of Democracy & $1045-5736$ & 380 & 0.663 \\
\hline Journal of Common Market Studies & $0021-9886$ & 152 & 0.653 \\
\hline $\begin{array}{l}\text { Armed Forces \& Society: An } \\
\text { Interdisciplinary Journal }\end{array}$ & $0095-327 X$ & 24 & 0.636 \\
\hline Acta Politica & $0001-6810$ & 19 & 0.605 \\
\hline Australian Journal of Political Science & $1036-1146$ & 105 & 0.582 \\
\hline Terrorism \& Political Violence & $0954-6553$ & 8 & 0.581 \\
\hline $\begin{array}{l}\text { Studies in Comparative International } \\
\text { Development }\end{array}$ & 0039-3606 & 49 & 0.571 \\
\hline Human Rights Quarterly & 0275-0392 & 566 & 0.565 \\
\hline Journal of Political Philosophy & $0963-8016$ & 105 & 0.562 \\
\hline
\end{tabular}




\begin{tabular}{|l|l|r|r|}
\hline Harvard International Journal of & $1081-180 \mathrm{x}$ & 47 & 0.561 \\
\hline Press/Politics & $0080-6757$ & 62 & 0.553 \\
\hline Scandinavian Political Studies & & & \\
\hline $\begin{array}{l}\text { Communist and Post-Communist } \\
\text { Studies }\end{array}$ & $0967-067 \mathrm{x}$ & 36 & 0.529 \\
\hline Public Choice & $0048-5829$ & 100 & 0.527 \\
\hline State Politics \& Policy Quarterly & $1532-4400$ & 2 & 0.524 \\
\hline Policy Studies Journal & $0190-292 \mathrm{x}$ & 161 & 0.515 \\
\hline Latin American Politics \& Society & $1531-426 \mathrm{x}$ & 123 & 0.509 \\
\hline Comparative Politics & $0010-4159$ & 85 & 0.489 \\
\hline Political Studies & $0032-3217$ & 169 & 0.488 \\
\hline Local Government Studies & $0300-3930$ & 0 & 0.486 \\
\hline Political Research Quarterly & $1065-9129$ & 227 & 0.486 \\
\hline Political Theory & $0090-5917$ & 294 & 0.453 \\
\hline International Political Science Review & $0192-5121$ & 316 & 0.450 \\
\hline Political Science \& Politics & $1049-0965$ & 303 & 0.430 \\
\hline East European Politics \& Societies & $0888-3254$ & 11 & 0.413 \\
\hline Problems of Post-Communism & $1075-8216$ & 10 & 0.368 \\
\hline Dissent & $0012-3846$ & 73 & 0.352 \\
\hline Nation & $0027-8378$ & 196 & 0.352 \\
\hline Monthly Review & $0027-0520$ & 207 & 0.344 \\
\hline Scottish Journal of Political Economy & $0036-9292$ & 19 & 0.343 \\
\hline Politische Vierteljahres Schrift & $0032-3470$ & 0 & 0.300 \\
\hline Parliamentary Affairs & $0031-2290$ & 161 & 0.298 \\
\hline Studies in American Political & & & \\
Development & $0898-588 \mathrm{x}$ & 0 & 0.263 \\
\hline Journal of Strategic Studies & $0140-2390$ & 13 & 0.260 \\
\hline Policy Review & $0146-5945$ & 106 & 0.245 \\
\hline Government and Opposition & $0017-257 x$ & 108 & 0.220 \\
\hline Independent Review & $1086-1653$ & 85 & 0.209 \\
\hline Commentary & $0010-2601$ & 247 & 0.204 \\
\hline Latin American Perspectives & $0094-582 x$ & 156 & 0.192 \\
\hline Current History & $0011-3530$ & 177 & 0.186 \\
\hline New Republic & $0028-6583$ & 63 & 0.175 \\
\hline The Political Quarterly & $0032-3179$ & 116 & 0.156 \\
\hline Revue D'economie Politique & $0373-2630$ & 0 & 0.113 \\
\hline Politikon: South African Journal of & & & \\
Political Studies & $0258-9346$ & 0 & 0.108 \\
\hline Chinese Law \& Government & $0009-4609$ & 0 & 0.091 \\
\hline Journal of Political and Military & & & \\
Sociology & $0047-2697$ & $1061-1940$ & 0.061 \\
\hline Russian Politics and Law & & 0.020 \\
\hline
\end{tabular}



Appendix 6.4: Environmental Science Discipline - VUW Usage Statistics and ISI
Impact Factors

\begin{tabular}{|c|c|c|c|}
\hline Journal Title & ISSN & $\begin{array}{l}\text { VUW } \\
\text { Usage } \\
2007\end{array}$ & $\begin{array}{l}\text { ISI Impact } \\
\text { Factor } \\
2007\end{array}$ \\
\hline Environmental Health Perspectives & $0091-6765$ & 125 & 5.636 \\
\hline Global Change Biology & $1354-1013$ & 111 & 4.786 \\
\hline $\begin{array}{l}\text { Critical Reviews in Environmental } \\
\text { Science Technology }\end{array}$ & 1064-3389 & 2 & 4.615 \\
\hline Environmental Science \& Technology & 0013-936X & 20601 & 4.363 \\
\hline $\begin{array}{l}\text { Frontiers in Ecology \& the } \\
\text { Environment }\end{array}$ & $1540-9295$ & 0 & 4.269 \\
\hline $\begin{array}{l}\text { Annual Reviews of Environment \& } \\
\text { Resources }\end{array}$ & $1543-5938$ & 77 & 4.036 \\
\hline Conservation Biology & $0888-8892$ & 2081 & 3.934 \\
\hline Global Environmental Change Part A & $0959-3780$ & 236 & 3.915 \\
\hline $\begin{array}{l}\text { Environmental Science \& Pollution } \\
\text { Research }\end{array}$ & 0944-1344 & 0 & 3.894 \\
\hline Ecological Applications & $1051-0761$ & 228 & 3.571 \\
\hline Water Research & 0043-1354 & 104 & 3.427 \\
\hline Biological Conservation & 0006-3207 & 1927 & 3.296 \\
\hline Applied Catalysis A: General & 0926-860X & 51 & 3.166 \\
\hline Environmental Pollution & $0269-7491$ & 137 & 3.135 \\
\hline Geobiology & $1472-4677$ & 0 & 3.114 \\
\hline Remote Sensing of Environment & $0034-4257$ & 69 & 3.013 \\
\hline $\begin{array}{l}\text { Journal of Environmental Science \& } \\
\text { Health Part C: Environmental } \\
\text { Carcinogenesis \& Ecotoxicology } \\
\text { Reviews }\end{array}$ & $1059-0501$ & 0 & 3.000 \\
\hline Environmental Research & 0013-9351 & 52 & 2.962 \\
\hline Climatic Change & 0165-0009 & 94 & 2.890 \\
\hline Environmental International & $0160-4120$ & 102 & 2.797 \\
\hline Chemosphere & $0045-6535$ & 148 & 2.739 \\
\hline $\begin{array}{l}\text { International Journal of Hydrogen } \\
\text { Energy }\end{array}$ & 0360-3199 & 60 & 2.725 \\
\hline Atmospheric Environment & $1352-2310$ & 115 & 2.549 \\
\hline Biogeochemistry & $0168-2563$ & 20 & 2.534 \\
\hline Ecotoxicology & $0963-9292$ & 11 & 2.405 \\
\hline $\begin{array}{l}\text { Environmental \& Molecular } \\
\text { Mutagenesis }\end{array}$ & 0893-6692 & 5 & 2.361 \\
\hline Aerosol Science \& Technology & $0278-6826$ & 0 & 2.350 \\
\hline Journal of Hazardous Materials & 0304-3894 & 73 & 2.337 \\
\hline Marine Pollution Bulletin & $0025-326 X$ & 1142 & 2.334 \\
\hline $\begin{array}{l}\text { Environmental Toxicology \& } \\
\text { Chemistry }\end{array}$ & $0730-7268$ & 14 & 2.309 \\
\hline $\begin{array}{l}\text { Agriculture Ecosystems \& } \\
\text { Environment }\end{array}$ & 0167-8809 & 292 & 2.308 \\
\hline Journal of Paleolimnology & $0921-2728$ & 37 & 2.287 \\
\hline Science of the Total Environment & $0048-9697$ & 324 & 2.182 \\
\hline Ecological Engineering & $0925-8574$ & 136 & 2.175 \\
\hline Estuaries & $0160-8347$ & 66 & 2.133 \\
\hline Environmental Modelling \& Software & $1364-8152$ & 83 & 2.099 \\
\hline $\begin{array}{l}\text { Ecotoxicology and Environmental } \\
\text { Safety }\end{array}$ & $0147-6513$ & 30 & 2.014 \\
\hline Journal of Industrial Ecology & $1088-1980$ & 2 & 1.962 \\
\hline Marine Environmental Research & $0141-1136$ & 128 & 1.930 \\
\hline
\end{tabular}




\begin{tabular}{|c|c|c|c|}
\hline Journal of Aerosol Science & $0021-8502$ & 6 & 1.902 \\
\hline Energy Policy & $0301-4215$ & 958 & 1.901 \\
\hline Journal of Contaminant Hydrology & $0169-7722$ & 9 & 1.852 \\
\hline Journal of Environmental Monitoring & $1464-0325$ & 16 & 1.833 \\
\hline Environmental \& Experimental Botany & $0098-8472$ & 35 & 1.810 \\
\hline $\begin{array}{l}\text { SAR \& QSAR in Environmental } \\
\text { Research }\end{array}$ & 1062-936X & 0 & 1.795 \\
\hline Environmental Toxicology & $1520-4081$ & 16 & 1.728 \\
\hline Geomicrobiology & 0149-0451 & 4 & 1.655 \\
\hline $\begin{array}{l}\text { Aquatic Sciences: Research Across } \\
\text { Boundaries }\end{array}$ & $1015-1621$ & 8 & 1.646 \\
\hline Journal of Atmospheric Chemistry & $0167-7764$ & 1 & 1.640 \\
\hline $\begin{array}{l}\text { Archives of Environmental } \\
\text { Contamination \& Toxicology }\end{array}$ & $0090-4341$ & 3 & 1.620 \\
\hline $\begin{array}{l}\text { International Journal of Life Cycle } \\
\text { Assessment }\end{array}$ & 0948-3349 & 3 & 1.607 \\
\hline Ecological Indicators & $1470-160 X$ & 92 & 1.576 \\
\hline $\begin{array}{l}\text { International Journal of } \\
\text { Biometeorology }\end{array}$ & $0020-7128$ & 3 & 1.562 \\
\hline River Research \& Applications & $1535-1459$ & 47 & 1.551 \\
\hline Ecological Economics & 0921-8009 & 1091 & 1.549 \\
\hline Ozone: Science \& Engineering & $0191-9512$ & 0 & 1.515 \\
\hline Ecohealth & $1612-9202$ & 9 & 1.492 \\
\hline $\begin{array}{l}\text { International Journal of } \\
\text { Phytoremediation }\end{array}$ & $1522-6514$ & 0 & 1.489 \\
\hline Ambio & $0044-7447$ & 51 & 1.487 \\
\hline Journal of Environmental Management & $0301-4797$ & 294 & 1.446 \\
\hline Biodiversity \& Conservation & $0960-3115$ & 159 & 1.421 \\
\hline Environmental Science and Policy & $1462-9011$ & 201 & 1.415 \\
\hline Environmental Forensics & $1527-5922$ & 0 & 1.412 \\
\hline Journal of Arid Environments & $0140-1963$ & 94 & 1.349 \\
\hline Waste Management & 0956-053X & 61 & 1.338 \\
\hline Environment & $0013-9157$ & 354 & 1.293 \\
\hline $\begin{array}{l}\text { Environmental Toxicology \& } \\
\text { Pharmacology }\end{array}$ & $1382-6689$ & 6 & 1.281 \\
\hline $\begin{array}{l}\text { Environmental Modeling \& } \\
\text { Assessment }\end{array}$ & $1420-2026$ & 17 & 1.279 \\
\hline Resources, Conservation \& Recycling & 0921-3449 & 164 & 1.270 \\
\hline Antarctic Science & 0954-1020 & 241 & 1.265 \\
\hline $\begin{array}{l}\text { Aquatic Conservation: Marine \& } \\
\text { Freshwater Ecosystems }\end{array}$ & $1052-7613$ & 88 & 1.240 \\
\hline Environmental Management & 0364-152X & 160 & 1.240 \\
\hline $\begin{array}{l}\text { International Biodeterioration \& } \\
\text { Biodegadation }\end{array}$ & 0964-8305 & 49 & 1.233 \\
\hline Water, Air \& Soil Pollution & 0049-6979 & 8 & 1.224 \\
\hline $\begin{array}{l}\text { Journal of Occupational Environmental } \\
\text { Hygiene }\end{array}$ & $1545-9624$ & 0 & 1.207 \\
\hline Journal of Environmental Engineering & $0733-9372$ & 4 & 1.174 \\
\hline Environmental Conservation & $0376-8929$ & 395 & 1.143 \\
\hline Water Environment Research & $1061-4303$ & 19 & 1.118 \\
\hline Environmental Geochemisty \& Health & $0269-4042$ & 2 & 1.086 \\
\hline Environmental Chemistry Letters & $1610-3653$ & 0 & 1.080 \\
\hline Journal of Cleaner Production & $0959-6526$ & 267 & 1.073 \\
\hline
\end{tabular}


Appendix 6.5: Mathematics Discipline - VUW Usage Statistics and ISI Impact Factors

\begin{tabular}{|c|c|c|c|}
\hline Journal Title & ISSN & $\begin{array}{l}\text { VUW } \\
\text { Usage } \\
2007\end{array}$ & $\begin{array}{l}\text { ISI Impact } \\
\text { Factor } \\
2007\end{array}$ \\
\hline Annals of Mathematics & $0003-486 \mathrm{X}$ & 11 & 2.739 \\
\hline $\begin{array}{l}\text { Communications on Pure \& Applied } \\
\text { Mathematics }\end{array}$ & $0010-3640$ & 4 & 2.696 \\
\hline ACTA Mathematica & $0001-5962$ & 2 & 2.560 \\
\hline $\begin{array}{l}\text { American Mathematical Society } \\
\text { Bulletin, New Series, of the American } \\
\text { Mathematica }\end{array}$ & 0273-0979 & 0 & 2.464 \\
\hline $\begin{array}{l}\text { Journal of the American Mathematical } \\
\text { Society }\end{array}$ & 0894-0347 & 0 & 2.000 \\
\hline $\begin{array}{l}\text { Foundations of Computational } \\
\text { Mathematics }\end{array}$ & $1615-3375$ & 0 & 1.833 \\
\hline Constructive Approximation & $0176-4276$ & 4 & 1.738 \\
\hline Inventiones Mathematicae & $0020-9910$ & 0 & 1.664 \\
\hline Publications Mathamatiques de L'Ihaos & $0073-8301$ & 0 & 1.286 \\
\hline Advances in Mathematics & $0001-8708$ & 26 & 1.235 \\
\hline $\begin{array}{l}\text { Proceedings of the London } \\
\text { Mathematical Society }\end{array}$ & 0024-6115 & 6 & 1.221 \\
\hline Computational Complexity & $1016-3328$ & 0 & 1.182 \\
\hline $\begin{array}{l}\text { Journal des Mathematiques Pures et } \\
\text { Appliques }\end{array}$ & $0021-7824$ & 5 & 1.118 \\
\hline Journal of Differential Equations & $0022-0396$ & 2 & 1.097 \\
\hline Nonlinear Analysis & $0362-546 \mathrm{X}$ & 2 & 1.097 \\
\hline Random Structures \& Algorithms & $1042-9832$ & 0 & 1.043 \\
\hline $\begin{array}{l}\text { Communications in Partial Differential } \\
\text { Equations }\end{array}$ & $0360-5302$ & 0 & 1.041 \\
\hline $\begin{array}{l}\text { Journal of the European Mathematical } \\
\text { Society }\end{array}$ & $1435-9855$ & 0 & 1.040 \\
\hline Geometric \& Functional Analysis & $1016-443 X$ & 3 & 1.026 \\
\hline $\begin{array}{l}\text { Annales Scientifiques de l'Ecole } \\
\text { Normale Superieure }\end{array}$ & $0012-9593$ & 0 & 1.019 \\
\hline $\begin{array}{l}\text { Journal of Combinatorial Theory: } \\
\text { Series B }\end{array}$ & 0095-8956 & 45 & 1.017 \\
\hline Interfaces \& Free Boundaries & $1463-9963$ & 0 & 1.000 \\
\hline American Journal of Mathematics & $0002-9327$ & 10 & 0.989 \\
\hline $\begin{array}{l}\text { Calculus of Variations \& Partial } \\
\text { Differential Equations }\end{array}$ & 0944-2669 & 0 & 0.985 \\
\hline Bulletin of Symbolic Logic & $1079-8986$ & 10 & 0.921 \\
\hline Journal of Functional Analysis & $0022-1236$ & 6 & 0.893 \\
\hline Compositio Mathematica & $0010-437 X$ & 0 & 0.882 \\
\hline Mathematische Annalen & $0025-5831$ & 1 & 0.877 \\
\hline Commentarii Mathematici hel Vetici & $0010-2571$ & 0 & 0.875 \\
\hline $\begin{array}{l}\text { Journal of Mathematical Analysis \& } \\
\text { Applications }\end{array}$ & $0022-247 X$ & 12 & 0.872 \\
\hline $\begin{array}{l}\text { Journal of the Institute of Mathematics } \\
\text { of Jussieu }\end{array}$ & $1474-7480$ & 0 & 0.853 \\
\hline Journal of Geometric Analysis & $1050-6926$ & 0 & 0.846 \\
\hline $\begin{array}{l}\text { Transactions of the American } \\
\text { Mathematical Society }\end{array}$ & $0002-9947$ & 28 & 0.824 \\
\hline Israel Journal of Mathematics & $0021-2172$ & 0 & 0.801 \\
\hline Selecta Mathematica: New Series & $1022-1824$ & 0 & 0.767 \\
\hline Lecture Notes in Mathematics & $0075-8434$ & 11 & 0.766 \\
\hline
\end{tabular}




\begin{tabular}{|l|l|r|r|}
\hline $\begin{array}{l}\text { Journal of Combinatorial Theory: } \\
\text { Series A }\end{array}$ & $0097-3165$ & 0 & 0.733 \\
\hline $\begin{array}{l}\text { Journal of the London Mathematical } \\
\text { Society }\end{array}$ & $0024-6107$ & 12 & 0.733 \\
\hline Computational Geometry & $0925-7721$ & 0 & 0.723 \\
\hline Transformation Groups & $1083-4362$ & 0 & 0.723 \\
\hline Journal of Approximation Theory & $0021-9045$ & 0 & 0.697 \\
\hline $\begin{array}{l}\text { Annali di Matematica Pura ed } \\
\text { Applicata }\end{array}$ & $0373-3114$ & 0 & 0.083 \\
\hline $\begin{array}{l}\text { Numerical linear algebra with } \\
\text { applications }\end{array}$ & $1070-5325$ & 0 & 0.182 \\
\hline Topology & $0040-9383$ & 1 & 0.217 \\
\hline Journal of Evolution Equations & $1424-3199$ & 0 & 0.684 \\
\hline Mathematische Zeitschrift & $0025-5874$ & 0 & 0.680 \\
\hline Journal of Pure and Applied Algebra & $0022-4049$ & 19 & 0.666 \\
\hline European Journal of Combinatorics & $0195-6698$ & 5 & 0.651 \\
\hline Ergodic Theory \& Dynamical Systems & $0143-3857$ & 0 & 0.645 \\
\hline Integral Equations \& Operator Theory & $0378-620 X$ & 0 & 0.645 \\
\hline Combinatorica & $0209-9683$ & 0 & 0.639 \\
\hline Journal of Algebra & $0021-8693$ & 88 & 0.630 \\
\hline Theory of Computing Systems & $1432-4350$ & 0 & 0.625 \\
\hline $\begin{array}{l}\text { Combinatorics, Probability \& } \\
\text { Computing }\end{array}$ & $0963-5483$ & 0 & 0.619 \\
\hline Discrete \& Computational Geometry & $0179-5376$ & 0 & 0.616 \\
\hline $\begin{array}{l}\text { Bulletin of the London Mathematical } \\
\text { Society }\end{array}$ & $0024-6093$ & 15 & 0.615 \\
\hline Annals of Pure \& Applied Logic & $0168-0072$ & 13 & 0.613 \\
\hline $\begin{array}{l}\text { The Quarterly Journal of Mathematics: } \\
\text { Oxford Series }\end{array}$ & $0033-5606$ & 0 & 0.612 \\
\hline Journal of Symbolic Logic & $0022-4812$ & 81 & 0.609 \\
\hline International Journal of Mathematics & $0129-167 X$ & 0 & 0.597 \\
\hline Journal of Algebraic Combinatorics & $0925-9899$ & 0 & 0.582 \\
\hline Acta Mathematica Sinica & $1439-8516$ & 0 & 0.562 \\
\hline $\begin{array}{l}\text { Communications in Contemporary } \\
\text { Mathematics }\end{array}$ & $0219-1997$ & 0 & 0.545 \\
\hline Applied Categorical Structures & $0927-2852$ & 0 & 0.538 \\
\hline Historia Mathematica & $0315-0860$ & 5 & 0.536 \\
\hline
\end{tabular}


Appendix 6.6: Physics (Applied) Discipline - VUW Usage Statistics and ISI Impact Factors

\begin{tabular}{|c|c|c|c|}
\hline Journal Title & ISSN & $\begin{array}{l}\text { VUW } \\
\text { Usage } \\
2007\end{array}$ & $\begin{array}{l}\text { ISI Impact } \\
\text { Factor } \\
2007\end{array}$ \\
\hline Nature Materials & $1476-1122$ & 276 & 19.782 \\
\hline $\begin{array}{l}\text { Materials Science \& Engineering R: } \\
\text { Reports }\end{array}$ & 0927-796X & 9 & 14.400 \\
\hline Advanced Functional Materials & $1616-301 X$ & 56 & 7.496 \\
\hline Small & $1613-6810$ & 99 & 6.408 \\
\hline Laser \& Particle Beams & $0263-0346$ & 0 & 4.696 \\
\hline Organic Electronics & $1566-1199$ & 3 & 3.879 \\
\hline Journal of Synchrotron Radiation & $0909-0495$ & 6 & 2.978 \\
\hline Quantum Electronics & $0018-9197$ & 11 & 2.360 \\
\hline Applied Physics B: Lasers \& Optics & $0946-2171$ & 2 & 2.280 \\
\hline $\begin{array}{l}\text { Progress in Photovoltaics: Research \& } \\
\text { Applications }\end{array}$ & $1062-7995$ & 6 & 2.179 \\
\hline $\begin{array}{l}\text { IEEE Transactions on Electron } \\
\text { Devices }\end{array}$ & $0018-9383$ & 11 & 2.165 \\
\hline Nanoscale Research Letters & $1931-7573$ & 4 & 2.158 \\
\hline Plasma Processes \& Polymers & $1612-8850$ & 0 & 2.132 \\
\hline IEEE Transactions on Nanotechnology & $1536-125 X$ & 9 & 2.110 \\
\hline $\begin{array}{l}\text { The European Physical Journal E: Soft } \\
\text { Matter }\end{array}$ & $1292-8941$ & 5 & 2.025 \\
\hline IEEE Photonics Technology Letters & $1041-1135$ & 15 & 2.015 \\
\hline $\begin{array}{l}\text { Photonics \& Nanostructures: } \\
\text { Fundamentals \& Applications }\end{array}$ & $1569-4410$ & 2 & 2.000 \\
\hline $\begin{array}{l}\text { Applied Physics A: Materials Science } \\
\text { \& Processing }\end{array}$ & $0947-8396$ & 90 & 1.857 \\
\hline $\begin{array}{l}\text { Journal of Electromagnetic Waves \& } \\
\text { Applications }\end{array}$ & $0920-5071$ & 0 & 1.844 \\
\hline $\begin{array}{l}\text { Plasma Chemistry \& Plasma } \\
\text { Processing }\end{array}$ & $0272-4324$ & 0 & 1.747 \\
\hline Thin Solid Films & $0040-6090$ & 194 & 1.693 \\
\hline Surface \& Coatings Technology & $0257-8972$ & 63 & 1.678 \\
\hline $\begin{array}{l}\text { Current Opinion in Solid State \& } \\
\text { Materials Science }\end{array}$ & $1359-0286$ & 11 & 1.677 \\
\hline Metrologia & $0026-1394$ & 0 & 1.667 \\
\hline Materials Letters & $0167-577 X$ & 256 & 1.625 \\
\hline $\begin{array}{l}\text { IEEE Transactions on Device \& } \\
\text { Materials Reliability }\end{array}$ & $1530-4388$ & 0 & 1.610 \\
\hline $\begin{array}{l}\text { IEEE Transactions on Applied } \\
\text { Superconductivity }\end{array}$ & $1051-8223$ & 21 & 1.551 \\
\hline Microelectronic Engineering & $0167-9317$ & 48 & 1.503 \\
\hline Philosophical Magazine & $1478-6435$ & 0 & 1.486 \\
\hline Applied Surface Science & $0169-4332$ & 145 & 1.406 \\
\hline IEEE Sensors Journal & $1530-437 X$ & 15 & 1.340 \\
\hline Journal of Electronic Materials & $0361-5235$ & 4 & 1.320 \\
\hline Current Applied Physics & $1567-1739$ & 157 & 1.291 \\
\hline Solid-State Electronics & $0038-1101$ & 11 & 1.259 \\
\hline Physica Status Solidi & $0031-8965$ & 33 & 1.214 \\
\hline Physica C: Superconductivity & $0921-4534$ & 94 & 1.079 \\
\hline Microelectronics Reliability & $0026-2714$ & 0 & 1.011 \\
\hline Cryogenics & $0011-2275$ & 7 & 0.981 \\
\hline Infrared Physics \& Technology & $1350-4495$ & 3 & 0.962 \\
\hline IEEE Transactions on Magnetics & $0018-9464$ & 131 & 0.959 \\
\hline
\end{tabular}




\begin{tabular}{|l|l|r|r|}
\hline Microsystem Technologies & $0946-7076$ & 3 & 0.912 \\
\hline Vacuum & $0042-207 \mathrm{X}$ & 15 & 0.881 \\
\hline Journal of Experimental Nanoscience & $1745-8080$ & 0 & 0.875 \\
\hline Optics \& Laser Technology & $0030-3992$ & 1 & 0.872 \\
\hline $\begin{array}{l}\text { IEEE Transactions on Dielectrics \& } \\
\text { Electrical Insulation }\end{array}$ & $1070-9878$ & 3 & 0.792 \\
\hline Journal of Low Temperature Physics & $0022-2291$ & 1 & 0.773 \\
\hline $\begin{array}{l}\text { IEEE Transactions on Semiconductor } \\
\text { Manufacturing }\end{array}$ & $0894-6507$ & 0 & 0.765 \\
\hline International Journal of Thermophysics & $0195-928 X$ & 0 & 0.698 \\
\hline Laser Physics & $1054-660 X$ & 0 & 0.696 \\
\hline Fluctuation \& Noise Letters & $0219-4775$ & 0 & 0.696 \\
\hline $\begin{array}{l}\text { Materials Science in Semiconductor } \\
\text { Processing }\end{array}$ & $1369-8001$ & 0 & 0.655 \\
\hline $\begin{array}{l}\text { International Journal of Modern } \\
\text { Physics B }\end{array}$ & $0217-9792$ & 0 & 0.647 \\
\hline $\begin{array}{l}\text { Nanoscale \& Microscale } \\
\text { Thermophysical Engineering }\end{array}$ & $1556-7265$ & 0 & 0.538 \\
\hline $\begin{array}{l}\text { Journal of Nonlinear Optical Physics \& } \\
\text { Materials }\end{array}$ & $0218-8635$ & 0 & 0.474 \\
\hline Technical Physics & $1063-7842$ & 0 & 0.460 \\
\hline Technical Physics Letters & $1063-7850$ & 1 & 0.449 \\
\hline $\begin{array}{l}\text { Journal of Superconductivity \& Novel } \\
\text { Magnetism }\end{array}$ & $1557-1939$ & 0 & 0.425 \\
\hline Modern Physics Letters B & $0217-9849$ & 0 & 0.400 \\
\hline Solid State Technology & $0038-111 X$ & 7 & 0.335 \\
\hline Integrated Ferroelectrics & $1058-4587$ & 0 & 0.334 \\
\hline High Temperature & $0018-151 X$ & 0 & 0.332 \\
\hline $\begin{array}{l}\text { International Journal of Applied } \\
\text { Electromagnetics \& Mechanics }\end{array}$ & $1383-5416$ & 0 & 0.305 \\
\hline $\begin{array}{l}\text { International Journal of Infrared \& } \\
\text { Millimeter Waves }\end{array}$ & $0195-9271$ & 0 & 0.300 \\
\hline $\begin{array}{l}\text { Journal of X-Ray Science \& } \\
\text { Technology }\end{array}$ & $0895-3996$ & 0 & 0.262 \\
\hline
\end{tabular}


Appendix 6.7: Economics Discipline - VUW Usage Statistics and ISI Impact Factors

\begin{tabular}{|c|c|c|c|}
\hline Journal Title & ISSN & $\begin{array}{l}\text { VUW } \\
\text { Usage } \\
2007\end{array}$ & $\begin{array}{l}\text { ISI Impact } \\
\text { Factor } \\
2007\end{array}$ \\
\hline Journal of Political Economy & $0022-3808$ & 333 & 4.190 \\
\hline Journal of Economic Literature & $0022-0515$ & 503 & 3.973 \\
\hline Quarterly Journal of Economics & $0033-5533$ & 227 & 3.688 \\
\hline Journal of Accounting \& Economics & $0165-4101$ & 130 & 3.034 \\
\hline Journal of Financial Economics & $0304-405 X$ & 315 & 2.988 \\
\hline Econometrica & $0012-9682$ & 263 & 2.972 \\
\hline Journal of Economic Perspectives & 0895-3309 & 418 & 2.831 \\
\hline Journal of Economic Geography & $1468-2702$ & 56 & 2.679 \\
\hline Review of Economic Studies & $0034-6527$ & 143 & 2.539 \\
\hline Journal of Economic Growth & $1381-4338$ & 71 & 2.292 \\
\hline American Economic Review & $0002-8282$ & 965 & 2.239 \\
\hline Economic Geography & 0013-0095 & 297 & 2.065 \\
\hline Journal of Econometrics & $0304-4076$ & 186 & 1.990 \\
\hline $\begin{array}{l}\text { Journal of Policy Analysis \& } \\
\text { Management }\end{array}$ & $0276-8739$ & 275 & 1.800 \\
\hline Review of Economics \& Statistics & $0034-6535$ & 123 & 1.724 \\
\hline The World Bank Research Observer & $0257-3032$ & 66 & 1.700 \\
\hline Economy \& Society & $0308-5147$ & 25 & 1.678 \\
\hline Health Economics & $1057-9230$ & 56 & 1.648 \\
\hline Journal of Law \& Economics & $0022-2186$ & 116 & 1.620 \\
\hline The Energy Journal & $0195-6574$ & 154 & 1.575 \\
\hline World Development & $0305-750 X$ & 1221 & 1.565 \\
\hline Energy Economics & $0140-9883$ & 154 & 1.557 \\
\hline Ecological Economics & 0921-8009 & 1091 & 1.549 \\
\hline Economic Journal & 0013-0133 & 433 & 1.548 \\
\hline Journal of International Economics & $0022-1996$ & 124 & 1.541 \\
\hline Journal of Health Economics & $0167-6296$ & 35 & 1.521 \\
\hline $\begin{array}{l}\text { Journal of Law Economics \& } \\
\text { Organization }\end{array}$ & $8756-6222$ & 90 & 1.488 \\
\hline Journal of Monetary Economics & 0304-3932 & 146 & 1.478 \\
\hline Journal of Labor Economics & 0734-306X & 84 & 1.473 \\
\hline Games \& Economic Behavior & $0899-8256$ & 22 & 1.468 \\
\hline Rand Journal of Economics & $0741-6261$ & 187 & 1.440 \\
\hline $\begin{array}{l}\text { Journal of Environmental Economics } \\
\text { \& Management }\end{array}$ & 0095-0696 & 151 & 1.438 \\
\hline $\begin{array}{l}\text { Brookings Papers on Economic } \\
\text { Activity }\end{array}$ & $0007-2303$ & 100 & 1.412 \\
\hline International Journal of Forecasting & $0169-2070$ & 29 & 1.409 \\
\hline Journal of Public Economics & $0047-2727$ & 114 & 1.403 \\
\hline Journal of Economic Theory & $0022-0531$ & 74 & 1.353 \\
\hline $\begin{array}{l}\text { Journal of Financial \& Quantitative } \\
\text { Analysis }\end{array}$ & $0022-1090$ & 116 & 1.342 \\
\hline Industrial and Corporate Change & $0960-6491$ & 117 & 1.325 \\
\hline Economic Policy & $0266-4658$ & 57 & 1.281 \\
\hline $\begin{array}{l}\text { European Review of Agricultural } \\
\text { Economics }\end{array}$ & $0165-1587$ & 19 & 1.271 \\
\hline The World Bank Economic Review & $0258-6770$ & 30 & 1.216 \\
\hline $\begin{array}{l}\text { Environmental and Resource } \\
\text { Economics }\end{array}$ & $0924-6460$ & 95 & 1.237 \\
\hline $\begin{array}{l}\text { Economic History Review: Second } \\
\text { Series }\end{array}$ & 0013-0117 & 331 & 1.171 \\
\hline
\end{tabular}




\begin{tabular}{|c|c|c|c|}
\hline Small Business Economics & 0921-898X & 220 & 1.168 \\
\hline The Journal of Human Resources & $0022-166 X$ & 110 & 1.162 \\
\hline $\begin{array}{l}\text { Journal of Business \& Economic } \\
\text { Statistics }\end{array}$ & 0735-0015 & 33 & 1.129 \\
\hline Experimental Economics & $1386-4157$ & 5 & 1.128 \\
\hline Journal of Risk \& Uncertainty & $0895-5646$ & 54 & 1.122 \\
\hline Journal of Applied Econometrics & $0883-7252$ & 44 & 1.094 \\
\hline Food Policy & $0306-9192$ & 66 & 1.056 \\
\hline Work, Employment \& Society & 0950-0170 & 114 & 1.051 \\
\hline Resource \& Energy Economics & $0928-7655$ & 60 & 1.050 \\
\hline Land Economics & $0023-7639$ & 195 & 1.042 \\
\hline $\begin{array}{l}\text { American Journal of Agricultural } \\
\text { Economics }\end{array}$ & $0002-9092$ & 343 & 1.034 \\
\hline Journal of Economic History & 0022-0507 & 360 & 1.015 \\
\hline Journal of Agricultural Economics & $0021-857 X$ & 12 & 1.000 \\
\hline $\begin{array}{l}\text { Review of International Political } \\
\text { Economy }\end{array}$ & $0969-2290$ & 45 & 1.000 \\
\hline European Economic Review & 0014-2921 & 167 & 0.994 \\
\hline Mathematical Finance & $0960-1627$ & 25 & 0.984 \\
\hline Review of Economic Dynamics & $1094-2025$ & 25 & 0.972 \\
\hline Journal of Money Credit \& Banking & $0022-2879$ & 172 & 0.947 \\
\hline Journal of Urban Economics & $0094-1190$ & 108 & 0.942 \\
\hline International Economic Review & $0020-6598$ & 68 & 0.917 \\
\hline Journal of Development Economics & $0304-3878$ & 294 & 0.912 \\
\hline Journal of Economic Psychology & $0167-4870$ & 167 & 0.900 \\
\hline Regional Science \& Urban Economics & 0166-0462 & 48 & 0.885 \\
\hline $\begin{array}{l}\text { Economic Development \& Cultural } \\
\text { Change }\end{array}$ & 0013-0079 & 176 & 0.875 \\
\hline $\begin{array}{l}\text { Journal of Economics \& Management } \\
\text { Strategy }\end{array}$ & $1058-6407$ & 41 & 0.875 \\
\hline $\begin{array}{l}\text { Journal of the European Economic } \\
\text { Association }\end{array}$ & $1542-4766$ & 6 & 0.871 \\
\hline The Journal of Industrial Economics & $0022-1821$ & 92 & 0.860 \\
\hline Futures & 0016-3287 & 1837 & 0.843 \\
\hline $\begin{array}{l}\text { Bulletin of Indonesian Economic } \\
\text { Studies }\end{array}$ & $0007-4918$ & 12 & 0.840 \\
\hline Post-Soviet Affairs & $1060-586 \mathrm{X}$ & 0 & 0.833 \\
\hline Quantitative Finance & $1469-7688$ & 3 & 0.824 \\
\hline Journal of Economic Surveys & 0950-0804 & 78 & 0.797 \\
\hline Journal of Regional Science & $0022-4146$ & 30 & 0.785 \\
\hline $\begin{array}{l}\text { Journal of Transport Economics \& } \\
\text { Policy }\end{array}$ & $0022-5258$ & 0 & 0.780 \\
\hline $\begin{array}{l}\text { Journal of Economic Behavior \& } \\
\text { Organization }\end{array}$ & $0167-2681$ & 195 & 0.772 \\
\hline Europe-Asia Studies & 0966-8136 & 168 & 0.770 \\
\hline Journal of Forest Economics & $1104-6899$ & 4 & 0.759 \\
\hline International Tax \& Public Finance & $0927-5940$ & 19 & 0.757 \\
\hline Journal of Banking \& Finance & $0378-4266$ & 142 & 0.753 \\
\hline Econometric Theory & $0266-4666$ & 40 & 0.748 \\
\hline Economics of Transition & $0967-0750$ & 24 & 0.736 \\
\hline $\begin{array}{l}\text { Oxford Bulletin of Economics \& } \\
\text { Statistics }\end{array}$ & $0305-9049$ & 33 & 0.732 \\
\hline The World Economy & $0378-5920$ & 247 & 0.715 \\
\hline Econometric Reviews & $0747-4938$ & 0 & 0.711 \\
\hline $\begin{array}{l}\text { Journal of Economic Dynamics \& } \\
\text { Control }\end{array}$ & $0165-1889$ & 77 & 0.703 \\
\hline
\end{tabular}




\begin{tabular}{|l|l|r|r|}
\hline New Political Economy & $1356-3467$ & 74 & 0.702 \\
\hline Cambridge Journal of Economics & $0309-166 \mathrm{X}$ & 111 & 0.700 \\
\hline Journal of Comparative Economics & $0147-5967$ & 43 & 0.691 \\
\hline Journal of Development Studies & $0022-0388$ & 166 & 0.686 \\
\hline Scandinavian Journal of Economics & $0347-0520$ & 83 & 0.676 \\
\hline Labour Economics & $0927-5371$ & 19 & 0.671 \\
\hline Explorations in Economic History & $0014-4983$ & 70 & 0.667 \\
\hline Journal of Common Market Studies & $0021-9886$ & 152 & 0.653 \\
\hline Oxford Economic Papers & $0030-7653$ & 81 & 0.645 \\
\hline Real Estate Economics & $1080-8620$ & 130 & 0.640 \\
\hline $\begin{array}{l}\text { The Australian Journal of Agricultural } \\
\text { \& Resource Economics }\end{array}$ & $1364-985 \mathrm{X}$ & 56 & 0.635 \\
\hline
\end{tabular}


Appendix 6.8: Information Science \& Library Science Discipline - VUW Usage Statistics and ISI Impact Factors

\begin{tabular}{|c|c|c|c|}
\hline Journal Title & ISSN & $\begin{array}{l}\text { VUW } \\
\text { Usage } \\
2007\end{array}$ & $\begin{array}{l}\text { ISI Impact } \\
\text { Factor } \\
2007\end{array}$ \\
\hline MIS Quarterly & $0276-7783$ & 1623 & 5.826 \\
\hline $\begin{array}{l}\text { Journal of the American Medical } \\
\text { Informatics Association }\end{array}$ & $1067-5027$ & 31 & 3.094 \\
\hline Information Systems Research & $1047-7047$ & 354 & 2.682 \\
\hline $\begin{array}{l}\text { Annual Review of Information Science } \\
\& \text { Technology }\end{array}$ & $0066-4200$ & 58 & 1.963 \\
\hline $\begin{array}{l}\text { Journal of Management Information } \\
\text { Systems }\end{array}$ & $0742-1222$ & 400 & 1.867 \\
\hline Journal of Health Communication & $1081-0730$ & 1 & 1.836 \\
\hline $\begin{array}{l}\text { International Journal of Geographical } \\
\text { Information Science }\end{array}$ & $1365-8816$ & 0 & 1.822 \\
\hline Information \& Management & $0378-7206$ & 712 & 1.631 \\
\hline Journal of Information Technology & 0268-3962 & 206 & 1.605 \\
\hline Information Systems Journals & $1350-1917$ & 110 & 1.531 \\
\hline $\begin{array}{l}\text { Information Processing \& } \\
\text { Management }\end{array}$ & $0306-4573$ & 182 & 1.500 \\
\hline Scientometrics & $0138-9130$ & 28 & 1.472 \\
\hline $\begin{array}{l}\text { Journal of the American Society for } \\
\text { Information Science \& Technology }\end{array}$ & $1532-2882$ & 271 & 1.436 \\
\hline $\begin{array}{l}\text { Journal of the Medical Library } \\
\text { Association }\end{array}$ & $1536-5050$ & 116 & 1.392 \\
\hline Journal of Documentation & $0022-0418$ & 408 & 1.309 \\
\hline $\begin{array}{l}\text { Journal of Global Information } \\
\text { Management }\end{array}$ & $1062-7375$ & 235 & 1.241 \\
\hline $\begin{array}{l}\text { Journal of Computer-Mediated } \\
\text { Communication }\end{array}$ & $1083-6101$ & 50 & 1.232 \\
\hline Journal of Information Science & $0165-5515$ & 120 & 1.080 \\
\hline Portal: Libraries \& the Academy & $1531-2542$ & 291 & 0.885 \\
\hline $\begin{array}{l}\text { Library \& Information Science } \\
\text { Research }\end{array}$ & $0740-8188$ & 233 & 0.870 \\
\hline College \& Research Libraries & $0010-0870$ & 621 & 0.820 \\
\hline Government Information Quarterly & $0740-624 X$ & 323 & 0.810 \\
\hline Law Library Journal & $0023-9283$ & 81 & 0.789 \\
\hline Serials Review & $0098-7913$ & 162 & 0.761 \\
\hline The Information Society & $0197-2243$ & 81 & 0.719 \\
\hline Online Information Review & $1468-4527$ & 452 & 0.671 \\
\hline $\begin{array}{l}\text { Library Resources \& Technical } \\
\text { Services }\end{array}$ & $0024-2527$ & 643 & 0.628 \\
\hline Telecommunications Policy & $0308-5961$ & 150 & 0.593 \\
\hline $\begin{array}{l}\text { Health Information and Libraries } \\
\text { Journal }\end{array}$ & $1471-1834$ & 47 & 0.592 \\
\hline Library Quarterly & 0024-2519 & 110 & 0.556 \\
\hline The Journal of Academic Librarianship & $0099-1333$ & 1255 & 0.551 \\
\hline Interlending \& Document Supply & $0264-1615$ & 215 & 0.533 \\
\hline Social Science Information & 0539-0184 & 33 & 0.523 \\
\hline $\begin{array}{l}\text { International Journal of Information } \\
\text { Management }\end{array}$ & $0268-4012$ & 314 & 0.451 \\
\hline Aslib Proceedings & $0001-253 X$ & 344 & 0.413 \\
\hline $\begin{array}{l}\text { Journal of Librarianship \& Information } \\
\text { Science }\end{array}$ & 0961-0006 & 118 & 0.405 \\
\hline Social Science Computer Review & 0894-4393 & 40 & 0.405 \\
\hline Online & $0146-5422$ & 505 & 0.368 \\
\hline
\end{tabular}




\begin{tabular}{|l|l|r|r|}
\hline Library Trends & $0024-2594$ & 964 & 0.333 \\
\hline Information Technology \& Libraries & $0730-9295$ & 604 & 0.326 \\
\hline The Scientist & $0890-3670$ & 62 & 0.322 \\
\hline Library Journal & $0363-0277$ & 2261 & 0.295 \\
\hline Journal of Scholarly Publishing & $1198-9742$ & 19 & 0.270 \\
\hline $\begin{array}{l}\text { Library Collections, Acquisitions \& } \\
\text { Technical Services }\end{array}$ & $1464-9055$ & 136 & 0.250 \\
\hline The Electronic Library & $0264-0473$ & 834 & 0.228 \\
\hline Econtent & $1525-2531$ & 433 & 0.196 \\
\hline Reference \& User Services Quarterly & $1094-9054$ & 533 & 0.175 \\
\hline Program & $0033-0337$ & 280 & 0.111 \\
\hline
\end{tabular}


Appendix 6.9: Management Discipline - VUW Usage Statistics and ISI Impact Factors

\begin{tabular}{|c|c|c|c|}
\hline Journal Title & ISSN & $\begin{array}{l}\text { VUW } \\
\text { Usage } \\
2007\end{array}$ & $\begin{array}{l}\text { ISI Impact } \\
\text { Factor } \\
2007\end{array}$ \\
\hline MIS Quarterly & $0276-7783$ & 1623 & 5.826 \\
\hline The Academy of Management Journal & $0001-4273$ & 1548 & 5.017 \\
\hline The Academy of Management Review & $0363-7425$ & 1795 & 4.372 \\
\hline Organization Science & $1047-7039$ & 699 & 3.130 \\
\hline Administrative Science Quarterly & $0001-8392$ & 861 & 2.912 \\
\hline Strategic Management Journal & 0143-2095 & 2312 & 2.829 \\
\hline $\begin{array}{l}\text { Academy of Management Learning } \\
\text { and Education }\end{array}$ & $1537-260 X$ & 47 & 2.796 \\
\hline Information Systems Research & $1047-7047$ & 354 & 2.682 \\
\hline Organizational Research Methods & $1094-4281$ & 207 & 2.548 \\
\hline $\begin{array}{l}\text { Journal of International Business } \\
\text { Studies }\end{array}$ & $0047-2506$ & 1589 & 2.283 \\
\hline Research Policy & $0048-7333$ & 253 & 2.211 \\
\hline Organization Studies & $0170-8406$ & 464 & 2.042 \\
\hline Journal of Management & $0149-2063$ & 840 & 2.000 \\
\hline Journal of Organizational Behavior & 0894-3796 & 523 & 1.981 \\
\hline Management Science & $0025-1909$ & 681 & 1.931 \\
\hline The Journal of Management Studies & $0022-2380$ & 734 & 1.926 \\
\hline $\begin{array}{l}\text { Journal of Management Information } \\
\text { Systems }\end{array}$ & $0742-1222$ & 400 & 1.867 \\
\hline Journal of Operations Management & $0272-6963$ & 238 & 1.851 \\
\hline $\begin{array}{l}\text { Organizational Behavior \& Human } \\
\text { Decision Processes }\end{array}$ & $0749-5978$ & 281 & 1.847 \\
\hline Leadership Quarterly & $1048-9843$ & 404 & 1.763 \\
\hline Long Range Planning & $0024-6301$ & 442 & 1.667 \\
\hline Information \& Management & $0378-7206$ & 712 & 1.631 \\
\hline Journal of Information Technology & $0268-3962$ & 206 & 1.605 \\
\hline Corporate Governance & $0964-8410$ & 174 & 1.590 \\
\hline $\begin{array}{l}\text { Journal of Product Innovation } \\
\text { Management }\end{array}$ & $0737-6782$ & 223 & 1.585 \\
\hline British Journal of Management & $1045-3172$ & 208 & 1.534 \\
\hline $\begin{array}{l}\text { International Journal of Management } \\
\text { Reviews }\end{array}$ & $1460-8545$ & 162 & 1.500 \\
\hline Decision Sciences & $0011-7315$ & 243 & 1.435 \\
\hline International Journal of Forecasting & $0169-2070$ & 29 & 1.409 \\
\hline Journal of Management Inquiry & $1056-4926$ & 209 & 1.338 \\
\hline Omega & $0305-0483$ & 654 & 1.327 \\
\hline Industrial \& Corporate Change & 0960-6491 & 117 & 1.325 \\
\hline Harvard Business Review & 0017-8012 & 5452 & 1.323 \\
\hline International Small Business Journal & $0266-2426$ & 179 & 1.250 \\
\hline Gender, Work \& Organization & $0968-6673$ & 140 & 1.185 \\
\hline Organization & $1350-5084$ & 388 & 1.169 \\
\hline Human Relations & $0018-7267$ & 584 & 1.103 \\
\hline $\begin{array}{l}\text { International Journal of Operations and } \\
\text { Production Management }\end{array}$ & 0144-3577 & 683 & 1.054 \\
\hline Technovation & $0166-4972$ & 297 & 1.004 \\
\hline $\begin{array}{l}\text { IEEE Transactions on Engineering } \\
\text { Management }\end{array}$ & 0018-9391 & 343 & 0.962 \\
\hline California Management Review & $0008-1256$ & 483 & 0.945 \\
\hline Supply Chain Management & $1359-8546$ & 297 & 0.913 \\
\hline Industrial Marketing Management & $0019-8501$ & 529 & 0.911 \\
\hline
\end{tabular}




\begin{tabular}{|c|c|c|c|}
\hline Tourism Management & $0261-5177$ & 1660 & 0.890 \\
\hline $\begin{array}{l}\text { European Journal of Work \& } \\
\text { Organizational Psychology }\end{array}$ & $1359-432 \mathrm{X}$ & 33 & 0.878 \\
\hline $\begin{array}{l}\text { Journal of Economics \& Management } \\
\text { Strategy }\end{array}$ & $1058-6407$ & 41 & 0.875 \\
\hline $\begin{array}{l}\text { New Technology, Work \& } \\
\text { Employment }\end{array}$ & $0268-1072$ & 60 & 0.870 \\
\hline MIT Sloan Management Review & $1532-9194$ & 96 & 0.849 \\
\hline $\begin{array}{l}\text { Journal of Organizational Behavior } \\
\text { Management }\end{array}$ & 0160-8061 & 2 & 0.818 \\
\hline $\begin{array}{l}\text { International Journal of Service } \\
\text { Industry Management }\end{array}$ & $0956-4233$ & 333 & 0.804 \\
\hline Group \& Organization Management & $1059-6011$ & 153 & 0.787 \\
\hline $\begin{array}{l}\text { Journal of the Operational Research } \\
\text { Society }\end{array}$ & $0160-5682$ & 113 & 0.784 \\
\hline Management Learning & $1350-5076$ & 128 & 0.738 \\
\hline $\begin{array}{l}\text { Journal of Small Business } \\
\text { Management }\end{array}$ & $0047-2778$ & 458 & 0.703 \\
\hline System Dynamics Review & $0883-7066$ & 112 & 0.656 \\
\hline Human Resource Management & $0090-4848$ & 760 & 0.642 \\
\hline $\begin{array}{l}\text { Technology Analysis \& Strategic } \\
\text { Management }\end{array}$ & $0953-7325$ & 55 & 0.638 \\
\hline $\begin{array}{l}\text { International Journal of Selection \& } \\
\text { Assessment }\end{array}$ & 0965-075X & 74 & 0.631 \\
\hline $\mathrm{R} \& \mathrm{D}$ Management & 0033-6807 & 104 & 0.597 \\
\hline Academy of Management Perspectives & $1558-9080$ & 55 & 0.594 \\
\hline Interfaces & $0092-2102$ & 90 & 0.575 \\
\hline Journal of Sport Management & $0888-4773$ & 0 & 0.556 \\
\hline $\begin{array}{l}\text { The International Journal of Human } \\
\text { Resource Management }\end{array}$ & $0958-5192$ & 154 & 0.546 \\
\hline Group Decision \& Negotiation & $0926-2644$ & 90 & 0.526 \\
\hline Research Technology Management & 0895-6308 & 311 & 0.476 \\
\hline Public Management Review & $1471-9037$ & 15 & 0.475 \\
\hline $\begin{array}{l}\text { Systems Research \& Behavioral } \\
\text { Science }\end{array}$ & $1092-7026$ & 175 & 0.467 \\
\hline Review of Industrial Organization & 0889-938X & 33 & 0.411 \\
\hline Journal of Forecasting & $0277-6693$ & 28 & 0.400 \\
\hline $\begin{array}{l}\text { Journal of Organizational Change } \\
\text { Management }\end{array}$ & $0953-4814$ & 751 & 0.360 \\
\hline $\begin{array}{l}\text { International Journal of Technology } \\
\text { Management }\end{array}$ & $0267-5730$ & 0 & 0.356 \\
\hline Organizational Dynamics & $0090-2616$ & 254 & 0.345 \\
\hline Negotiation Journal & $0748-4526$ & 182 & 0.340 \\
\hline $\begin{array}{l}\text { Betriebswirtschaftliche Forschung und } \\
\text { Praxis }\end{array}$ & $0340-5370$ & 0 & 0.294 \\
\hline $\begin{array}{l}\text { Total Quality Management \& Business } \\
\text { Excellence }\end{array}$ & $1478-3363$ & 22 & 0.278 \\
\hline Service Industries Journal & 0264-2069 & 198 & 0.210 \\
\hline Systemic Practice \& Action Research & 1094-429X & 50 & 0.194 \\
\hline International Journal of Manpower & $0143-7720$ & 481 & 0.188 \\
\hline $\begin{array}{l}\text { Revue Canadienne des Sciences de } \\
\text { l'Administration/Canadian Journal of } \\
\text { Administrative Sciences }\end{array}$ & $0825-0383$ & 98 & 0.119 \\
\hline
\end{tabular}


Appendix 6.10: Law Discipline - VUW Usage Statistics and ISI Impact Factors

\begin{tabular}{|c|c|c|c|}
\hline Journal Title & ISSN & $\begin{array}{l}\text { VUW } \\
\text { Usage } \\
2007\end{array}$ & $\begin{array}{l}\text { ISI Impact } \\
\text { Factor } \\
2007\end{array}$ \\
\hline Harvard Law Review & $0017-811 X$ & 317 & 5.859 \\
\hline Columbia Law Review & 0010-1958 & 116 & 3.363 \\
\hline UCLA Law Review & $0041-5650$ & 0 & 3.091 \\
\hline Texas Law Review & $0040-4411$ & 31 & 3.062 \\
\hline The Yale Law Journal & $0044-0094$ & 440 & 2.821 \\
\hline $\begin{array}{l}\text { University of Pennsylvania Law } \\
\text { Review }\end{array}$ & 0041-9907 & 78 & 2.817 \\
\hline California Law Review & $0008-1221$ & 67 & 2.770 \\
\hline Stanford Law Review & $0038-9765$ & 168 & 2.517 \\
\hline Virginia Law Review & $0042-6601$ & 90 & 2.506 \\
\hline Psychology, Public Policy \& Law & $1076-8971$ & 0 & 2.400 \\
\hline Georgetown Law Journal & 0016-8092 & 18 & 2.356 \\
\hline Michigan Law Review & $0026-2234$ & 266 & 2.266 \\
\hline Journal of Legal Studies & $0047-2530$ & 35 & 1.972 \\
\hline Northwestern University Law Review & 0029-3571 & 21 & 1.899 \\
\hline Vanderbilt Law Review & $0042-2533$ & 21 & 1.768 \\
\hline $\begin{array}{l}\text { The American Bankruptcy Law } \\
\text { Journal }\end{array}$ & $0027-9048$ & 0 & 1.756 \\
\hline New York University Law Review & 0028-7881 & 0 & 1.722 \\
\hline Journal of Law \& Economics & $0022-2186$ & 116 & 1.620 \\
\hline $\begin{array}{l}\text { Journal of Criminal Law \& } \\
\text { Criminology }\end{array}$ & $0091-4169$ & 318 & 1.559 \\
\hline Law \& Human Behavior & $0147-7307$ & 227 & 1.551 \\
\hline $\begin{array}{l}\text { The University of Chicago Law } \\
\text { Review }\end{array}$ & $0041-9494$ & 96 & 1.489 \\
\hline $\begin{array}{l}\text { Journal of Law Economics \& } \\
\text { Organization }\end{array}$ & $8756-6222$ & 90 & 1.488 \\
\hline Duke Law Journal & $0012-7086$ & 66 & 1.420 \\
\hline Iowa Law Review & $0021-0552$ & 15 & 1.301 \\
\hline Stanford Journal of International Law & $0731-5082$ & 6 & 1.286 \\
\hline Law \& Society Review & $0023-9216$ & 172 & 1.283 \\
\hline Journal of International Economic Law & $1369-3034$ & 249 & 1.274 \\
\hline The American Criminal Law Review & $0164-0364$ & 73 & 1.253 \\
\hline $\begin{array}{l}\text { The American Journal of International } \\
\text { Law }\end{array}$ & $0002-9300$ & 553 & 1.191 \\
\hline Administrative Law Review & $0001-8368$ & 0 & 1.186 \\
\hline Common Market Law Review & $0165-0750$ & 26 & 1.117 \\
\hline The Business Lawyer & $0007-6899$ & 13 & 1.100 \\
\hline American Journal of Law \& Medicine & 0098-8588 & 14 & 1.091 \\
\hline Antitrust Law Journal & $0003-6056$ & 0 & 1.055 \\
\hline Journal of Law Medicine \& Ethics & $1073-1105$ & 124 & 1.042 \\
\hline Behavioral Sciences \& the Law & $0735-3936$ & 134 & 1.033 \\
\hline Law \& Social Inquiry & $0897-6546$ & 138 & 0.933 \\
\hline $\begin{array}{l}\text { Harvard Journal of Law \& Public } \\
\text { Policy }\end{array}$ & $0193-4872$ & 59 & 0.912 \\
\hline American Business Law Journal & $0002-7766$ & 101 & 0.889 \\
\hline European Journal of International Law & $0938-5428$ & 133 & 0.836 \\
\hline $\begin{array}{l}\text { Harvard Civil Rights: Civil Liberties } \\
\text { Law Review }\end{array}$ & $0017-8039$ & 0 & 0.815 \\
\hline Psychology, Crime \& Law & 1068-316X & 11 & 0.815 \\
\hline Law Library Journal & $0023-9283$ & 81 & 0.789 \\
\hline
\end{tabular}




\begin{tabular}{|l|l|r|r|}
\hline $\begin{array}{l}\text { International Journal of Law \& } \\
\text { Psychiatry }\end{array}$ & $0160-2527$ & 125 & 0.766 \\
\hline The Washington Quarterly & $0163-660 X$ & 88 & 0.723 \\
\hline Supreme Court Review & $0081-9557$ & 7 & 0.706 \\
\hline American Journal of Comparative Law & $0002-919 X$ & 90 & 0.699 \\
\hline $\begin{array}{l}\text { Annual Review of Law \& Social } \\
\text { Science }\end{array}$ & $1550-3585$ & 0 & 0.543 \\
\hline Washington Law Review & $0043-0617$ & 1 & 0.535 \\
\hline Journal of Law \& Society & $0263-323 X$ & 147 & 0.519 \\
\hline Journal of Maritime Law \& Commerce & $0022-2410$ & 2 & 0.488 \\
\hline Judicature & $0022-5800$ & 8 & 0.485 \\
\hline European Journal of Migration \& Law & $1388-364 X$ & 0 & 0.424 \\
\hline Legal \& Criminological Psychology & $1355-3259$ & 6 & 0.400 \\
\hline Law \& Philosophy & $0167-5249$ & 26 & 0.359 \\
\hline $\begin{array}{l}\text { International Journal of Constitutional } \\
\text { Law }\end{array}$ & $1474-2640$ & 49 & 0.352 \\
\hline Journal of Legal Medicine & $0194-7648$ & 5 & 0.350 \\
\hline Social \& Legal Studies & $0964-6639$ & 108 & 0.326 \\
\hline $\begin{array}{l}\text { Columbia Journal of Law \& Social } \\
\text { Problems }\end{array}$ & $0010-1923$ & 0 & 0.280 \\
\hline $\begin{array}{l}\text { International Review of Law \& } \\
\text { Economics }\end{array}$ & $0144-8188$ & 75 & 0.273 \\
\hline $\begin{array}{l}\text { Ocean Development \& International } \\
\text { Law }\end{array}$ & $0090-8320$ & 14 & 0.273 \\
\hline Issues in Law \& Medicine & $8756-8160$ & 38 & 0.250 \\
\hline European Constitutional Law Review & $1574-0196$ & 1 & 0.234 \\
\hline Family Law Quarterly & $0014-729 X$ & 0 & 0.186 \\
\hline $\begin{array}{l}\text { International Journal of the Sociology } \\
\text { of Law }\end{array}$ & $0194-6595$ & 42 & 0.148 \\
\hline Juvenile \& Family Court Journal & $0161-7109$ & 0 & 0.111 \\
\hline Natural Resources Journal & $0028-0739$ & 0 & 0.111 \\
\hline Chinese Law \& Government & $0009-4609$ & 0 & 0.091 \\
\hline & & & \\
\hline
\end{tabular}




\section{BIBLIOGRAPHY}

Altmann, K.G. and Gorman, G.E. (1999). Can impact factors substitute for the results of local use studies?: findings from an Australian case study. Collection Building, 18(2), 90-94.

Altmann, K.G. and Gorman, G.E. (1998). The usefulness of impact factors in serial selection: a rank and mean analysis using ecology journals. Library Acquisitions: Practice and Theory, 22(2), 147-159.

Bergstrom, C. (2007). Eigenfactor: measuring the value and prestige of scholarly journals. College and Research Libraries News 68(5), 314-416.

Bergstrom, C. (2009). Why Eigenfactor. Retrieved January 15, 2009, from http://www.eigenfactor.org/whyeigenfactor.htm.

Chung, H. (2007). Evaluating academic journals using impact factor and local citation score. The Journal of Academic Librarianship, 33(3), 393-402.

COUNTER. (2006). About COUNTER. Retrieved January 15, 2009, from http://www.projectcounter.org/about.html.

Duy, J. and Vaughan, L. (2006). Can electronic journal usage data replace citation data as a measure of journal use?: an empirical examination. Journal of Academic Librarianship, 32(5), 512-517.

Garfield, E. (1990). How ISI selects journals for coverage: quantitative and qualitative considerations. Current Contents, 22, 5-13.

Hafner, A.W. (1998). Descriptive statistical techniques for librarians (2 ed.). London: American Library Association.

Hernon, P. (1994). Statistics: a component of the research process (rev. ed.). Norwood: Ablex Publishing Corporation.

ISI Web of Knowledge. (2008). Journal Citation Reports. Retrieved January 15, 2009 from http://isiwebofknowledge.com/products tools/analytical/jcr/. 
Levitt, J.M. and Thelwall, M. (2008). Is multidisciplinary research more highly cited? A macrolevel study. Journal of the American Society for Information Science and Technology, 59(2), 1973-1984.

Nisonger, T.E. (2004). The benefits and drawbacks of impact factor for journal collection management in libraries. The Serials Librarian, 47(1/2), 57-75.

Nixon, W. and Wulff, J.L. (2004). Quality markers and use of electronic journals in an academic health services library. Journal of the Medical Library Association, 92(3), 315-322.

Pickard, A.J. (2007). Research Methods in Information. London: Facet Publishing.

Red Jasper's Centre for Journal Ranking. (2006). The Magnitude of Journal Ranking. Retrieved January 15, 2009 from http://journalranking.com/ranking/web/index.html.

Rousseau, R. (2002). Journal evaluation: technical and practical issues. Library Trends, 50(3) 418-441.

Saha, S. (2003). Impact factor: a valid measure of journal quality? Journal of the Medical Library Association, 91(1), 42-46.

SCImago. (2007). SJR — SCImago Journal \& Country Rank. Retrieved January 15, 2009, from http://www.scimagojr.com.

Scopus. (2008). Scopus in Detail. Retrieved January 15, 2009, from http://info.scopus.com/detail/what/.

Seglen, P.O. (1997). Why the impact factor of journals should not be used for evaluating research. British Medical Journal (International Edition), 314, 498502.

SPARC. (2007). Innovators: Ted Bergstrom and Carl Bergstrom. Retrieved January, 15, 2009, from http://www.arl.org/sparc/innovator/bergstroms.html.

Tsay, M. (1998). The relationship between journal use in a medical library and citation use. Bulletin of the Medical Library Association, 86(1), 31-39.

Zwemer, R.L. (1970). Identification of journal characteristics useful in improving input and output of a retrieval system. Federation Proceedings, 29, 1595-1604. 
Word count (excluding abstract, contents, appendixes and bibliography) $=9,390$ words. 